\title{
월드프렌즈코리아(WFK) 중장기 전략 수립을 위한 해외봉사 성과 측정 동향 분석
}

구영은 (KOICA 월드프렌즈총괄실 전문관) 최경화 (KOICA 월드프렌즈총괄실 전문관)

목 차

I. 연구 배경 및 소개

II. 해외봉사 성과 측정 논의

1. 배경과 흐름

2. 현황 분석

III. 이론적 접근

1. 비용효과성 접근

2. 모니터링과 평가 이론

3. 논리모형

4. 논리모형의 적용

5. 삼각측량법

NV. SDGs 달성을 위한 측정

1. 해외봉사단의 SDGs 기여 측정 현황

2. mapping 모델

V. 도전과제

VI. 종합분석 및 결론

참고문헌 


\section{요 약}

2016년 지속가능개발목표(SDGs)의 세부 목표와 지표가 합의되고, 봉사활동이 $\mathrm{SDGs}$ 이행에 강력하고 범분야적인 수단임이 강조된 현 시점에서, 해외봉사를 통한 $\mathrm{SDGs}$ 달성 성과의 증명은 점점 중요해질 추세이다. 이러한 추세에 맞추어 전 세계 해외봉사 파견기관 및 관련 학계는 해외봉사의 성과 측정에 대한 연구에 박차를 가하고 있다. 그러나 현재까지 해외봉사 성과 증명의 방법론에 있어서 전 세계적 합의가 도출되 지 않은 실정이며, 이는 바로 전세계 다양한 해외봉사 프로그램의 목적, 형태, 규모, 예산 등에 있어서 큰 차이가 있기 때문이라고 할 수 있다. 실제로 각국의 각기 다른 해외봉사 파견조직이 수행한 성과 평가 연구는 그 목적, 성과 지표, 보고 방법, 평가의 품질 등에 있어서 차이가 있기 때문에 조직별, 프로그램별로 체계적인 성과 비교조차 사실상 불가능한 상황이다. 따라서 현재 해외봉사 성과 측정에 관련된 국제적 논의와 도전과제를 검토하고 분석하여, $\mathrm{WFK}$ 사업에 적용 가능한 성과 평가의 중장기 전략을 모색하는 작업이 필요한 시점이라 할 수 있다. 금번 연구에서는 해외봉사의 성과 측정에 대한 동향을 해외 최신문헌 검토를 통하여 분석해보고자 하며, 그 분석 결과를 바탕으로 $\mathrm{WFK}$ 사업을 SDGs와 연계한 성과 평가 중장기 전략 수립 방향을 모색하고자 한다.

주제어: 월드프렌즈코리아, 봉사, 성과 측정, SDGs, 논리모형

\section{I. 연구 배경 및 소개}

해외봉사단 파견 사업은 1951년 호주 멜버른 대학교 자원봉사 대학원생 제도(Volunteer Graduate Scheme) 개설과 호주 해외봉사단(Australian Volunteers International, 이하 AVI) 창설을 기점으로, 1958년 영국 해외봉사단(Voluntary Service Overseas, 이하 VSO), 1961년 미국 평화봉사단(Peace Corps), 1970년 국제연합 봉사단(United Nations Volunteers, 이하 UNV) 설립 등을 통해 그 규모가 전 세계적으로 퍼졌다. 한국도 1991년 국제협력단(Korea International Cooperation Agency, 이하 KOICA) 설립과 동시에 해외봉사단을 파견하기 시작하였으며, 특히 KOICA가 담당하는 월드프렌즈 해외봉사단 파견 사업(World Friends Korea, 이하 WFK)은 한국의 대표적인 국민 참여형 협력 사업으로, 연평균 1,600 명 내외의 단원들이 전 세계 60 여 개국에서 교육, 보건의료, 행정제도, 정보통신, 산업에너지, 농어촌 개발, 
환경 분야 관련 50 여개 직종에서 활동하고 있다1).

해외봉사단 파견 사업의 초점은 시작부터 다양한 변화의 과정을 거쳤는데, 특히 과거 195060년대까지는 그 목적이 식민주의에 근거한 북-남 기술이전에 치중해있던 반면, 1960-70년대 부터는 지역·풀뿌리(grassroots) 관점과 사람중심 접근 강화(예: bottom-up 접근, 남남 봉사 활동 등장), 1980-90년대에는 시장중심 접근 강화, 2000년대부터는 시민인권의식 강화, 2000 년대 중반부터는 해외봉사의 성과·데이터 중심 접근 강화와 함께 볼런투어리즘(volontourism) 및 기업 봉사 등 새로운 참여 형태의 봉사활동이 등장하기 시작하였다(Franco-Shahrokh, 2015:20-22). 이 가운데, 2000년대 중반부터 현재까지 해외봉사의 영향2)과 성과 측정이 지속적 으로 강조되고 있는 점은 $\mathrm{WFK}$ 사업을 담당하고 있는 $\mathrm{KOICA}$ 가 전사적으로 주목해야 할 사실이며, 이것이 바로 동 연구의 초점이 되겠다.

특히 2016년 지속가능개발목표(Sustainable Development Goals, 이하 SDGs)의 세부 목표와 지표가 합의되고, 봉사활동이 SDGs 이행에 “강력하고 범분야적인 수단(UN, 2014)"임 이 강조된 현 시점에서, 해외봉사를 통한 SDGs 달성 성과의 증명은 점점 중요해질 추세이다. 이러한 추세에 맞추어 전 세계 해외봉사 파견기관 및 관련 학계는 해외봉사의 성과관리, 모니터 링과 평가(Monitoring and Evaluation, 이하 M\&E) 등에 대한 연구에 박차를 가하고 있다. 한국도 관련 연구 수행실적을 보유하고 있으나, 기존의 국내연구3)에서는 해외봉사 M\&E 관련 국외 최신 문헌 검토 및 SDGs와 WFK 간의 성과 연계 등이 다소 부족했기 때문에 WFK 중장기 전략을 위한 구체적 방안의 수립에 국내 연구들이 적절히 활용되지 못하고 있다.

게다가 현재까지 해외봉사 성과 증명의 방법론에 있어서 전 세계적 합의가 도출되지 않은 실정이며, 이는 바로 전 세계 다양한 해외봉사 프로그램의 목적, 형태, 규모, 예산 등에 있어서 큰 차이가 있다는 점 때문이라 할 수 있다. 실제로 각국의 각기 다른 해외봉사 파견조직이 수행한 성과 평가 연구를 보면 그 목적, 성과의 지표, 보고 방법, 평가의 품질 등에 있어서 차이가 있기 때문에 조직별, 프로그램별, 국가별로 체계적인 성과 비교조차 사실상 불가능한 상황이다. 따라서 현재 해외봉사 성과 측정에 관련된 국제적 논의와 도전과제를 검토하고 분석 하여, $\mathrm{WFK}$ 사업에 적용 가능한 질 높은 성과 평가의 중장기 전략을 모색하는 작업이 필요한 시점이라 할 수 있다.

1) 월드프렌즈코리아 홈페이지를 참조하기 바란다. (http://www.worldfriendskorea.or.kr/ view/intro.program.do) (접속일: 2016.11.25.)

2) 영향력(impact)이란 여러 개의 결과가 성취되었을 때 나타날 수 있는 장기적 관점의 이익 및 성과를 말하며, MDGs 및 SDGs가 그 예이다(Morra-Imas·Morra·Rist, 2009:138).

3) 예를 들어 이태주 외(2016), 주성수 외(2016), 홍문숙 외(2016) 연구가 있다. 
이러한 목표를 염두에 두고, 앞선 1 차 연구에서는 수원국 중심의 해외봉사단 성과 요소를 검토하고 재분류함으로써 WFK 사업의 수원국 중심 성과요소 수립을 위한 제언을 도출하였다 (구영은 외, 2016). 본 연구에서는 성과 측정 접근법에 대한 동향을 해외 최신문헌 검토를 통하여 분석해보고자 한다. 아울러 그 분석 결과를 바탕으로 WFK 사업을 SDGs와 연계한 성과 평가 중장기 전략 수립 방향을 모색해보고자 한다.

\section{II. 해외봉사 성과 측정 논의}

\section{1. 배경과 흐름}

해외봉사의 성과 측정은 2000년대 중반부터 강조되기 시작했으며, 그 우선순위는 지금까지 수차례 변화를 거쳤다. 우선 1950년대 해외봉사단 초기에는 성과 평가에 대한 인식이 낮았으며, 단순한 투입물(봉사단 인원, 국가 등)에 대한 데이터는 지속적으로 추적하였으나 산출물과 결과 에 대해서는 거의 추적하지 않았다. 또 봉사단의 목표와 우선순위는 명확히 제시를 하더라도, 목표 달성을 위한 활동 방식은 봉사단원 스스로가 설정할 수 있는 권한을 주었다. 이와 함께 M\&E는 최소한으로만 실시되었다(Lough, 2015:18).

1960년대에 해외봉사활동이 성행하기 시작할 당시 경제성장 모델이 간단했고 서비스 전달을 위한 수요도 방대하였으므로 단순한 투입물 측정으로도 모니터링이 충분했다. 또한 봉사 사업의 모델도 간단하여 파견기간 2 년, 북 남 방향 등으로 그 형태가 일정했으며, 측정도 봉사단원 파견규모와 봉사단원 중심(중도 포기자 인원 등)으로 간단했다. 그러나 봉사단 파견단체가 진화 할수록 이러한 단순한 평가 방식에 대한 문제가 드러나기 시작했다(Allum, 2016).

봉사단 평가의 가장 기본이 되는 수혜자 인원 추적과 같은 경우에도 1970 년대에는 미국 평화봉사단 정도만 추적하고 있었으며, 봉사활동 결과나 성과는 봉사단원 개인이 제일 잘 알기 때문에 일괄적 평가가 불필요하다는 주장도 존재했다(Lough, 2015:19). 하지만 개발 협력 사업의 책무성이 강조되면서 결과 중심 문화 역시 해외봉사단 전반에 걸쳐 퍼지기 시작하였고, 기록의 보관 및 보고 체계 구축 등 복잡한 평가 시스템이 도입되기 시작했다(Lough, 2015:19). 특히 해외봉사단의 다양성 도래와 봉사활동의 가치 증명에 대한 압박 등은 기존의 단순한 방식 의 측정 방법에 점점 더 많은 의문을 제기했다(Allum, 2016). 
1990년대 말부터 해외 원조와 공적개발원조(Official Development Assistance, 이하 $\mathrm{ODA}$ )에서 결과 중심 관리가 중요한 요소로 자리를 잡으면서, 봉사단이 개발목표 달성에 어떻 게 기여하는지를 증명하라는 요구가 가중되었다. 이에 따라 봉사단의 영향, 효과성, 효율성, 투명성, 비구속성 등의 증명에도 관심과 탐구가 시작되었다(Lough, 2015:18).

2000년도에는 새천년개발목표(Millennium Development Goals, MDGs) 달성을 위한 봉 사단의 기여를 측정 및 증명하려는 노력이 전개되었으며, 과거 후진적 측정 접근법(예: 단순한 파견 인원 확장 및 취업률 증가 등을 강조하는 투입물 위주)에 대한 공여국의 불만이 드러나기 시작했다. 더불어 학계와 실무자 간의 관계가 강화되면서 개도국 지역사회가 진정으로 무엇을 필요로 하는지를 조사하는 노력이 전개되었다(Allum, 2016). 측정의 관심사는 과거 단순한 투입물이었던 것에서 산출물(예: 봉사단원 중심의 성과 등의 output)로 바뀌었고, 여기에서 다시 보다 고차원적인 결과물(예: 봉사단원 및 개도국 지역사회의 변화 등을 포함한 outcome) 로 발전했다. 또한 정확히 무엇을 측정할 것인지에 대해서도 심도 있는 논의가 시작되었는데, 이러한 논의를 통하여 해외봉사 측정을 위한 노력이 가중되고 해외봉사 성과 평가 접근, 이론, 모델 또한 발전했다.

그러나 이러한 노력이 해외봉사 성과 측정의 품질 향상으로 이어지고 있다고 단정 짓기는 어렵다. 그 이유는 최근 영국 등지에서 청년 중심의 봉사 사업이 확장되면서 장기적 영향보다는 또 다시 투입물 위주의 성과 측정(예: 파견 인원 확장, 취업 확장 등)을 강조하는 기조로 퇴보하 고 있기 때문이다. 따라서 현재는 해외봉사 이해관계자들이 '개발을 위한 봉사(Volunteering for Development, 이하 $\mathrm{V} 4 \mathrm{D})$ '의 가치에 대해 보다 확신을 갖고, 측정에 관한 이론과 모델에 도약이 필요한 시기라 할 수 있다(Allum, 2016).

최근 Post-2015 개발체제의 구축과 함께 전 세계 봉사단 파견기관은 SDGs 로의 기여를 위한 성과 측정 방안 마련에 박차를 가하고 있다(Lough, 2015:19). 특히 봉사활동이 개발에 주는 성과에 관심이 쏠리면서 기존의 단순하며 임시변통적인 측정 접근법에서 벗어나, 사회적 자본(social capital) 접근, 봉사활동의 가치(예: 경제적 가치 등), SDGs 이행을 위한 메커니즘, 성과 관련 증거와 증거의 품질 등이 중요시되고 있는 추세라 할 수 있다.

\section{2. 현황 분석}

최근 해외봉사의 M\&E와 관련하여 Franco and Shahrokh(2012), Haddock and Devereux (2015), Lough, Thomas and Asbill(2015) 등 다수 연구팀이 조사한 바 있다(<표 1> 참고). 
〈표 1〉 주요 선행 연구 요약

\begin{tabular}{|c|c|c|}
\hline 연구 수행자 & 내용 & 주요 주제 \\
\hline $\begin{array}{l}\text { Franco } \\
\text { Shahrokh } \\
(2012)\end{array}$ & $\begin{array}{l}\text { 봉사의 가치(성과) 측정 및 M\&E 관련 이 } \\
\text { 론적 고찰과 최근의 연구 동향 분석 }\end{array}$ & $\begin{array}{l}\text { - 영향 측정 이론 } \\
\text { - 측정을 위한 최근 노력 } \\
\text { - M\&E의 목적, 비판, 교훈 }\end{array}$ \\
\hline $\begin{array}{l}\text { Haddock } \\
\text { Devereux } \\
\text { (2015) }\end{array}$ & $\begin{array}{l}\text { 해외봉사활동의 성과 측정 현황을 분석 } \\
\text { 하고 SDGs 달성을 위한 봉사활동의 성 } \\
\text { 과 측정법(mapping) 등 획기적인 방안을 } \\
\text { 제시 }\end{array}$ & $\begin{array}{l}\text { - 측정 주요 기준 및 측정 현황 } \\
\text { - SDGs 달성을 위한 봉사의 기여측정 방 } \\
\text { 안 }\end{array}$ \\
\hline $\begin{array}{l}\text { Lough · } \\
\text { Thomas · Asbill } \\
\text { (2015) }\end{array}$ & $\begin{array}{l}\text { 회색문헌(grey literature) 연구를 통해 해 } \\
\text { 외봉사의 성과를 중재하는 요소를 분석 } \\
\text { 하고, 해외봉사의 M\&E에 있어서 문제점 } \\
\text { 과 도전과제를 지적 }\end{array}$ & $\begin{array}{l}\text { - 해외봉사 성과 중재 요소 } \\
\text { - 해외봉사 성과 연구의 문제점 } \\
\text { - M\&E의 문제점 \& 도전과제 }\end{array}$ \\
\hline
\end{tabular}

출처: 저자 구성

Lough et al.(2015)는 8개의 해외봉사 파견기관으로부터 수행된 124 개의 보고서를 수집하 여 회색문헌 연구를 수행함으로써, 해외봉사 사업 $\mathrm{M} \& \mathrm{E}$ 의 현황을 종합적으로 분석하였다.4) Lough 외(2015)가 조사한 대다수의 보고서는 현재 해외봉사 사업에 M\&E 체계가 부족하다는 점을 거론했으며, 따라서 해외봉사 사업의 성과 평가에 대해 단정 짓는 것이 불가능하다고 결론을 내렸다. 대다수의 보고서는 해외봉사 사업의 내부적 운영 사이클만 평가할 뿐 프로젝트 의 결과물이나 장기적인 영향은 측정하지 않았다. 더불어 몇 개의 보고서들은 특정 산출물의 목록을 단순히 제시하기만 할 뿐, 산출물에서 더 나아간 영향 수준의 성과는 논의하지 않았다 (Lough et al., 2015:18).

다수의 보고서에서는 $\mathrm{M} \& \mathrm{E}$ 체계 부족의 원인을 모니터링 과정의 불충분성, 평가 도구의 약점, 데이터 수집의 비일관성, 평가 설계의 품질 결여, 평가 프로세스의 기본적 결함 등이라 지적하였다(Lough et al., 2015:18). 예를 들어, 해외봉사 사업의 효과성에 대해 입증되지 않은 (anecdotal) 평가 데이터 혹은 주관적인 평가 자료(예: 설문지에 자가 응답)에 의존하거나, 해외봉사 사업의 영향이 발견되더라도 영향을 보고하는 방법의 정확성이 부재하다는 점이 다수 지적되었다. 이는 해외봉사 사업의 성과에 대한 지식이 제대로 공유되거나 확산되지 않고 있다 는 것을 암시한다(Lough et al., 2015:18).

4) 회색문헌 연구는 출판되지 않았거나 널리 배포되지 않은 연구들을 활용함으로써 중복 연구를 피하고, 기관이 공개하지 않은 솔직한 데이터를 분석할 수 있다는 장점이 있다. 동 Lough et al.(2015)의 회색문헌 연구에는 호주, 뉴질랜드, 영국, 노르웨이, 캐나다, 스위스, 싱가포르, 독일의 사례가 포함됐으며, KOICA 사례는 제외되었다. 
이처럼 해외봉사 사업의 성과 평가를 위한 일관적 체계가 부족한 현실에서, Haddock and $\operatorname{Devereux}(2015)$ 는 해외봉사활동의 성과 보고를 가능하도록 하기 위해서는 <표 2>와 같이 몇 가지 주요 기준을 충족해야 한다고 설명한다.

〈표 2〉해외봉사 사업 성과 평가(데이터 수집, 측정, 보고)의 주요 기준

\begin{tabular}{c|l}
\hline 기준 & \multicolumn{1}{c}{ 내용 } \\
\hline 적절성 & $\begin{array}{l}\text { 수집된 정보는 해외봉사 사업의 세부적 맥락, 활동, 정책목표를 반영해야 하며, 사업 } \\
\text { 과 관련 없는 정보는 과감히 수집을 지양해야 함. 데이터에 관한 정보는 지역사회와 } \\
\text { 봉사단원에게 유용해야 함. }\end{array}$ \\
\hline 현실적 & $\begin{array}{l}\text { 다양한 수준에서 세부 사항을 고려해야 하며, 봉사활동 성과 측정을 위한 기술 뿐 } \\
\text { 아니라 측정에 동원되는 직원과 봉사단원 확보에도 노력이 필요함. }\end{array}$ \\
\hline 효율적 & $\begin{array}{l}\text { 데이터와 관련 정보는 가급적 해외봉사 파견기관의 기존 데이터 수집 및 보고의 } \\
\text { 틀 안에서 구축되어야 함. }\end{array}$ \\
\hline 비교 가능 & $\begin{array}{l}\text { 데이터와 정보의 폭넓은 활용을 위해, 기관 간 그리고 국가 간 정보의 비교가 가능해 } \\
\text { 야 함. }\end{array}$ \\
\hline 신뢰적, 객관적 & $\begin{array}{l}\text { 데이터와 정보는 누가 수집했는지에 상관없이 시간이 지나도 반복적으로 동일한 데이터가 수집되어 동일한 트렌드를 보이도록 설계되어야야고 함. 즉, 정보각 가능해야 하며, 다른 출처부터 삼각측량(triangulation)을 통해 검증 } \\
\text { 되어야 함. }\end{array}$ \\
\hline
\end{tabular}

출처: Haddock and Devereux (2015) p.26 재구성

<표 2>에 의하면 데이터 수집, 측정, 보고의 적절성, 현실성, 효율성, 비교가능성, 신뢰성 및 객관성이 보장되어야만 해외봉사 사업의 성과 평가가 가능한 것인데, WFK 사업의 경우 현행 적용되고 있는 주요 평가 방법인 1) 봉사단원 활동보고서, 2) 단원 다면평가, 3) 현지 평가회의, 4) 기관장 회의, 5) WFK 종합 만족도조사(예: KOICA, 2016a) 중에서 위 다섯 가지 기준을 모두 충족하는 평가는 없다고 볼 수 있다. 예를 들어, 봉사단원 활동보고서는 봉사 단원이 직접 수기로 작성하여 자가 평가를 하는 형식이고, WFK 종합 만족도조사는 사업에 대한 봉사단원과 협력기관의 만족도를 조사하는 것이기 때문에(자가 평가 설문) 엄밀히 말하면 진정한 성과를 측정한다고 볼 수 없으며, 나머지 단원 다면평가, 현지 평가회의, 기관장 회의는 질적 평가가 주를 이루기 때문에 평가의 신뢰성과 객관성이 부족하다고 볼 수 있다. WFK 사업은 이러한 평가체계의 한계를 인식하고 현재 WFK 성과관리 지표개발5) 및 성과지표 고도 화 작업을 추진하고 있다. ${ }^{6}$ )

5) 자세한 내용은 홍문숙 외(2016)를 참고하기 바란다.

6) 미국의 평화봉사단, 영국의 ICS 및 $\mathrm{VSO}$, 호주 AVID, 일본 JOCV 등도 성과 평가 모형, 방법론, 가치사슬 등의 확립을 추진 중이며, 타국 사례에 대한 보다 자세한 조사는 추후 연구에서 다루기로 하겠다. 
한편 Franco and Shahrokh(2012)와 Haddock and Devereux(2015)는 해외봉사 M\&E 의 장점을 강조하고 있다. 예를 들어, Franco and Shahrokh(2012:28)는 해외봉사 사업 M\&E 수행을 통해 사업의 영향 평가 수행뿐만 아니라, 사업의 운영방법 향상, 사업 전략의 조율, 이해관계자들의 주인의식(ownership) 향상, 프로그램 관계자의 책임성을 다룰 수 있도록 역량 구축, 학습의 공유 등이 가능하다고 명시한다. 더불어 해외봉사 M\&E 관련 지식공유와 학습을 통해 1) 다수 이해관계자의 책임감 독려, 2) 프로그램 전달 향상, 3) 프로그램 전략의 세밀화, 4) 사회적 자본 강화 및 개발, 5) 글로벌 공공재 창출이 가능하다고 주장하면서, 궁극적으로 해외봉사의 $\mathrm{M} \& \mathrm{E}$ 의 가장 중요한 목적은 포괄과 학습, 인센티브를 통해 가난한 지역사회에 긍정적 영향을 창출하는 것임을 강조한다(Franco·Shahrokh, 2012:28). 이는 M\&E를 수행함 으로써 얻는 학습이 사업 수행에 못지않게 개도국 지역사회 개발에 중요하다는 점을 시사한다.

이와 같은 해외봉사 사업 성과 측정에 대한 필요성과 인식 증가는 성과 측정의 이론적 접근에 대한 관심 또한 고조시키고 있다. 이와 함께 봉사 사업의 비용적 가치 평가 접근, $\mathrm{M} \& \mathrm{E}$ 접근, 해외봉사 사업의 논리모형 접근 등에 대한 논의가 활발히 이루어지고 있다.

\section{III. 이론적 접근}

\section{1. 비용효과성 접근}

봉사활동 평가에 있어서 국제사회가 우선시하는 점 중 하나는 봉사단원이 주는 경제적 이익 이다. 이는 봉사활동의 금전적 가치(value for money)를 측정함으로써 봉사 사업이 개발문제 를 해결하는데 얼마나 비용 효과적인지를 증명하는 것이다. 봉사활동의 금전적 가치 계산을 위해 필요한 정보는 1) 인구 샘플(population sample), 2) 샘플 중 봉사자 인원, 그리고 3) 봉사자 1 인당 봉사활동에 종사한 시간이다. 샘플 중 봉사자의 비율에 총 성인 인구를 고려함으로써 총 봉사자 인원수를 계산하고, 이 수를 봉사자가 봉사활동에 종사하는 평균 시간에 곱한다. 마지막으로 봉사자가 봉사활동에 임한 총 시간을 그림자임금(shadow wage) 혹은 금전적 가치(monetary value)에 곱하면, 봉사활동시간의 금전적 값이 나온다(Franco·Shahrokh, 2012:24).

자원봉사의 경제적 가치를 풀타임 노동의 비중으로 환산하는 방식은 여러 국가에서 일반화되 고 있는데, 예를 들어 2010년 미국의 18세 이상 자원봉사자 약 6천만 명의 경제적 가치는 자원봉사 시간(81억 시간)에 시간당 $21.36 \mathrm{USD}$ 를 곱해서 약 1,690 억 USD로 추산되었다(주성 수 외, 2012:25). 한국에서도 2011년 자원봉사자 833만 명(연평균 100.4시간)의 활동을 시간당 
평균임금(당시 15,933 원)으로 환산하면 약 13 조 원(국내총생산의 $1.13 \%$ )의 경제적 가치가 있는 것으로 추산되었다(주성수 외, 2012:25). 이 수치는 몽고의 국내총생산(Gross Domestic Product, GDP) 수준과 비슷하다. 이는 자원봉사의 대가 없는 노동이 국가경제에 대한 기여가 높다는 점을 시사한다.7) WFK 봉사단원의 금전적 가치는 지금까지 추론된 적은 없으나, 활동기 간이 1-2년 이상(장기봉사단)인 월드프렌즈 KOICA 봉사단의 경우를 예로 들어 그 가치를 추산해 볼 수 있다. 즉, 2015년을 기준으로 총 922명의 활동인원(KOICA, 2016d:7)과 활동지원 금(연간 1 인당 약 1 만 5 천 USD로 가정)의 데이터를 바탕으로 계산해 본다면, 2015년 약 13.8 백 만 $\mathrm{USD}$, 한화 기준 약 160 억 원의 경제적 가치를 무상노동의 형태로 개도국에 기부한 것으로 계산된다. 중기봉사단과 단기봉사단의 데이터도 고려하여 합산한다면 그 경제적 가치가 더욱 크게 책정될 것이다.

제I 장

봉사활동의 성과 평가로 비용효과성을 환산하는 것은 그 가치를 간단한 수치로 내세울 수 있다는 장점이 있지만, 초점이 지나치게 좁고 단면적이라 비추어질 수 있다. 예컨대 봉사활동의 경제적 기여는 봉사활동이 사회에 주는 많은 혜택 중 극히 일부만을 대표하는 것이다(UNV, 2011b:13). 봉사활동의 금전적 혜택을 강조하여 그 가치를 평가하는 것 또한 봉사활동의 근본적 인 비대가성 희생정신을 위협할 수도 있다. 따라서 봉사활동의 비용적 가치 이외에도 여러 방면을 아울러 중장기적 효과성을 평가하는 것이 봉사활동의 진정한 가치를 측정하는데 용이하 다고 할 수 있다. 이를 위해 M\&E 접근 방식을 활용할 수 있다.

\section{2. 모니터링과 평가 이론}

모니터링(monitoring)이란 프로그램, 프로젝트, 정책 등의 진행 상황이나 목적 달성 정도를 측정하기 위해 특정 지표에 대해 지속적인 데이터를 수집하고 활용하는 활동을 말한다 (Morra-Imas·Morra·Rist, 2009:34), 평가(evaluation)란 프로그램, 프로젝트, 정책 등의 가 치에 대해 확인 및 측정하는 활동이다(Morra-Imas et al., 2009:24). M\&E는 모두 성과를 측정하고 검토하는 행위라고 볼 수 있으며, 모니터링은 프로그램/프로젝트의 시행단계 전반에 걸쳐 시행되는 내부적 활동인 반면 평가는 모니터링을 통한 자료를 기반으로 ‘왜'라는 질문에 대한 답을 모색하는 과정이라 할 수 있다(Morra-Imas et al., 2009:35).

$\mathrm{M} \& \mathrm{E}$ 접근으로 해외봉사의 가치를 입증하는 것은 앞에서 알아본 해외봉사의 금전적 가치

7) 동 수치는 무급 자원봉사에 한정된 것이며, 이러한 경제적 가치를 해외봉사에 무조건적으로 적용하면 안 될 것이다. 왜냐하면 해외봉사는 자원봉사와는 달리 활동비를 제공해주는 경우가 많은데, 엄밀히 말하면 대가가 따르는 봉사활동 은 자원봉사에 속하지 않는다. 한국 자원봉사활동 기본법에서 자원봉사의 개념을 "개인 또는 단체가 지역사회, 국가 및 인류사회를 위하여 대가없이 자발적으로 시간과 노력을 제공하는 행위(3조1항)"로 정의하고 있기 때문이다. 
환산에 따른 지나친 단순함과 단면성을 보완해줄 수 있다. 이에 따라 해외봉사의 $\mathrm{M} \& \mathrm{E}$ 연구 에 대한 관심도 점점 증가하는 추세이다. 그러나 봉사 사업 $\mathrm{M} \& \mathrm{E}$ 수행의 혜택에 대한 인식 부족, $\mathrm{M} \& \mathrm{E}$ 로의 노력을 위한 장려 부족, 그리고 $\mathrm{M} \& \mathrm{E}$ 가 비교적 개방적이지 않은 분야라는 점은 $\mathrm{M} \& \mathrm{E}$ 수행에 대한 의지를 꺾고 있다(Franco-Shahrokh, 2012:24). 그리고 인과관계 (causality)와 관련한 문제도 있는데, 즉, $\mathrm{M} \& \mathrm{E}$ 를 통해 단원이 활동하는 지역사회에서 주민들 의 생활이 개선됨을 발견하더라도, 이러한 개선이 봉사 사업으로 인한 결과라고 단정할 수 없다는 것이다. 때문에 아직도 많은 학계와 이해관계자들은 $\mathrm{M} \& \mathrm{E}$ 의 방법론적 견고성에 대해 의구심을 갖는다. '인과관계에 대한 전쟁(the causal war)'으로도 불리는 이러한 현상 속에서, $\mathrm{M} \& \mathrm{E}$ 의 주요 접근법에는 <표 $3>$ 과 같이 큰 차이가 있거나 서로 상충되기도 한다.

〈표 3〉 개발사업의 모니터링과 평가(M\&E) 관련 주요 입장

\begin{tabular}{|c|c|}
\hline 접근법 & 설명 \\
\hline $\begin{array}{c}\text { 실험적 평가 } \\
\text { (Experimental) }\end{array}$ & $\begin{array}{l}\text { 실험적 방법론을 적용한 평가가 보다 '과학적(scientific)'인 방법이라는 가정이 } \\
\text { 널리 퍼져있으며, 유럽·미국 등지의 정책평가 커뮤니티 내에서 실험적 접근에 } \\
\text { 대한 강한 지지를 보임. 특히 무작위대조연구(Randomised Controlled Trials, } \\
\mathrm{RCT} \text { 는 프로그램 평가에 있어 가장 견고한 과학적 접근을 제공해줌. 무작위대조 } \\
\text { 연구 수행이 어려운 경우, 반 사실적·사후 가정(counterfactual) 디자인이 구상되 } \\
\text { 어야 함. }\end{array}$ \\
\hline $\begin{array}{l}\text { 변화이론 } \\
\text { (Theories of } \\
\text { Change) }\end{array}$ & $\begin{array}{l}\text { 프로그램이 얼마나 바람직한 성과를 거두었는지에 대한 이론임. 결과의 어느 } \\
\text { 정도가 프로그램으로 인한 것인지 평가가 가능토록 M\&E 체계 구상을 도와줌. } \\
\text { 프로그램이 성공실패했는지에만 초점을 맞추기보다는, 왜 그러한 결과가 있었는 } \\
\text { 지 분석하는 것에 비중을 둠. 변화이론은 프로그램을 설계하고 평가하는 혁신적 } \\
\text { 도구이자, 프로그램의 장기적 목표 달성에 필요한 구성요소의 청사진을 보여줌. } \\
\text { 변화이론의 구성에 있어서 논리모형의 논리와 타당성, 사회적 요구를 반영했는지 } \\
\text { 여부, 각 요소의 정의, 프로젝트가 명시한 목적의 현실적 달성 가능 여부, 요소들 } \\
\text { 간의 논리적 연계성과 일관성 등의 검토가 필요함. }\end{array}$ \\
\hline $\begin{array}{l}\text { 현실적 평가 } \\
\text { (Realistic } \\
\text { Evaluation) }\end{array}$ & $\begin{array}{l}\text { 프로그램은 대체로 복잡하고 역동적이며, 프로그램의 이행과정에 참여하는 사람 } \\
\text { 들은 다양한 특성, 지각, 태도를 지니고 있음. 이러한 역동성은 프로그램의 다양한 } \\
\text { 구성요소에 대한 참여자의 반응을 구체화시키며, 때문에 프로그램의 효과성을 } \\
\text { 단정할 수 있는 증거의 확보가 어려움. 따라서 현실적 평가의 목표는 프로그램 } \\
\text { 구조에서 가장 흠미로운 요소를 발견하고, 이러한 요소들이 특정 개인/그룹에게 } \\
\text { 어떻게 성과를 주는지를 탐구하는 것임. 이를 위해 지식공유/향상에 비중을 두어 } \\
\text { 평가계회을 설계하고 현재 혹은 향후 프로그램의 디자인을 조정함. 때문에 현실 } \\
\text { 적 평가는 체계적 학습(systematic learning)에 초점을 맞추는 경향이 있으며, } \\
\text { 책임성(accountability)에 대해서는 거의 다루지 않음. }\end{array}$ \\
\hline
\end{tabular}

출처: Franco and Shahrokh (2012) p.27 및 Morra-Imas et al.(2009)의 내용을 저자가 재구성

위에서 명시한 접근법 중 실험적 접근(예: 무작위대조연구(Randomised Controlled Trials, 이하 RCT))이 인과관계 및 영향을 증명해주는 가장 신뢰도 높고 과학적인 방법이라는 입장이 
다수를 차지한다. 그러나 실험적 접근이나 $\mathrm{RCT}$ 방법을 해외봉사 사업 평가에 적용하는 것은 거의 불가능하다고 할 수 있다. 그 이유는 여러 가지가 있지만, 특히 해외봉사활동을 포함한 사회사업의 다양한 결과물을 비교 가능한 항목과 수치로 계량화 하는 것이 어렵기 때문이다 (Franco-Shahrokh, 2012:24). 예컨대, WFK 사업의 경우, 6개의 시행기관이 특징, 활동기간, 주력 활동 분야 등 성격이 상이한 8개의 각기 다른 WFK 프로그램을 시행하고 있는 관계로, $\mathrm{WFK}$ 사업 결과를 통합적인 계량화 하는 것이 지속적인 난관으로 대두되고 있다. 이러한 해외 봉사활동 결과의 비교와 계량화에 대한 어려움은 비단 한국뿐 아니라 $\mathrm{UNV}$ 를 포함한 국제기구 및 타국 해외봉사단도 공감하는 부분이기도 하다.

이 밖에도, 해외봉사 사업의 효과성을 실험하기 위한 환경을 만들기 위하여 봉사 서비스가 필요한 개도국 주민을 '수혜집단' vs. '통제집단(control group)'으로 분리하여 일부에게만 서 비스를 제공하고, 봉사활동 환경을 최대한 통제하여 실험기간 동안 수혜자들이 봉사활동 이외에 다른 혜택을 받지 못하도록 '외부요인’을 통제함으로써, 해외봉사활동의 효과성에 대한 견고한 증명을 과학적으로 입증하는 것이 과연 현실적이거나 윤리적으로 합당한지에 대해서도 의문이 들 수 있다.

이렇듯 견고한 실험을 통하여 해외봉사 사업을 평가하는 것이 현실적이거나 윤리적이지 못할 수 있기 때문에, 다수 조직들은 변화이론(theories of change)을 보다 실용적이며 획기적인 옵션으로 여기고 있다. 변화이론은 특정 개발 사업이 어떻게 의도한 결과를 도출할 수 있을지를 보여주는 모형이며, 전형적인 변화이론 모형은 5 가지 요소(투입물, 활동, 산출물, 결과, 영향)로 구성된다. 변화이론의 주요 특징은 $\mathrm{RCT}$ 와는 달리 개발목표 달성을 위한 지침이라고 볼 수 있으며, 필요시 사업 방향의 전환과 학습에 있어서 융통성을 제공해주는 장점이 있다(Franco. Shahrokh, 2012:27).

한편, 몇몇의 기관 및 연구진들은 현실적 평가(Realistic Evaluation)를 지향하며, 각각의 프로젝트를 고유적인(unique) 실험이라고 주장하고 있다. 즉, 프로젝트가 지역사회에 가져다주 는 고유한 사회적 변화가 프로젝트의 결과에 결정적인 효과를 미친다는 입장이다. 이러한 입장 에는 만일 타 지역이나 인구를 대상으로 같은 프로젝트를 반복해서 시행했을 때 성과가 일관적 이지 않을 수도 있다는 단점이 따른다(Franco·Shahrokh, 2012:27).

상기 3가지의 접근 방법을 보완하기 위해, Franco and Shahrokh 등이 2012년부터 2014년 까지 진행한 '봉사의 가치(Valuing Volunteering)' 연구 프로젝트는 봉사활동 결과의 고유성을 현지 지역사회의 문맥과 연계하고, 연구자가 현지에서 갖는 위치도 고려하면서 봉사활동의 가치를 평가한 바 있다. 특히 동 연구는 현실적 평가 접근과는 달리 책임성과 권한(accountability and 
power)에 관한 이슈도 자세히 들여다보고, 지역사회에 내재되어 있는 권위 관계(power relations)와 이해관계자들 간에 벌어지는 역동성을 분석함으로써, 봉사활동의 가치에 대해 문맥을 고려한 체계적이며 광범위한 연구를 추진하였다(참고: Burns et al., 2015).

상기 $\mathrm{M \& E}$ 접근법 중 영국 $\mathrm{VSO}$ 는 현실적 평가와 가치연구 접근법을 적용하고 있으며, $\mathrm{UNV}$ 는 변화이론에 관한 연구와 이의 적용을 활발히 진행한 바 있다. WFK 사업의 성과모형 수립에 있어서도 변화이론(논리모형)의 적용이 주를 이루고 있는데, 예를 들어, 홍문숙 외 (2016)의 WFK 성과관리 지표개발 연구 및 이태주 외(2016)의 WFK 종합평가 보고서에서는 변화이론을 변형한 형태인 논리모형을 적용한 바 있다.

\section{3. 논리모형}

UNV (2011a:11) 및 Haddock and Devereux(2015:38)는 봉사의 개발 성과를 측정하기 위한 도구로서 전반적 논리모형(general logical framework)8)의 활용을 강조한 바 있다. 논리모 형은 변화이론 모델을 변형한 형태로, 활동, 성과, 목적 등을 포함한 프로젝트의 주요 요소를 간결하며 체계적으로 구성하여 표 또는 프레임워크 형식으로 도식화하여 보여준다(<표 $4>$ 참고).

\section{〈표 4〉 논리모형이 포함하는 내용}

\begin{tabular}{c|l}
\hline 내용 & \multicolumn{1}{c}{ 설명 } \\
\hline 목표와 목적 & $\begin{array}{c}\text { 프로그램의 종합적 목표(overall goal)부터 세부 목적(specific goals)까지 } \\
\text { 무엇을 달성해야 할 것인지를 명시 }\end{array}$ \\
\hline 질문과 지표 & 진전도(progress)를 모니터링 하는데 사용할 성과 관련 질문과 지표 명시 \\
\hline $\begin{array}{c}\text { 모니터링 및 데이터 } \\
\text { 수집 방법 }\end{array}$ & 지표가 어떻게 모니터링 되고, 데이터가 어떻게 수집될 지를 명시 \\
\hline 가정(assumption) & $\begin{array}{c}\text { 논리모형에 명시된 세부 활동들이 궁극적으로 어떻게 목표 달성에 기여하는 } \\
\text { 지에 대한 가정(assumption)을 명시 }\end{array}$ \\
\hline 위험요소 & 목표 달성과 관련한 위험요소(risk)를 명시 \\
\hline
\end{tabular}

출처: UNV (2011a) p.11 정리 및 재구성

논리모형은 개발활동을 계획 및 평가하는 세계 각 기관이 조직 수준, 프로그램 수준, 프로젝트 수준에서 사용하고 있으며, 전반적으로 해외봉사 사업의 모니터링과 성과 평가에 유용한 프레임

8) 로그프레임(logical framework/logframe)이라고도 일컨는다. 
워크를 제공해 주기 때문에 타 해외봉사 관련 기관들에서도 점점 보편화되고 있다. WFK 사업 의 경우에도 논리모형을 활용하여 2016년 WFK 사업 통합 성과모형(안)이 고안된 바 있으며 (홍문숙 외, 2016), 동 모형은 현재 실질적 적용 여부를 판단키 위해 적정성 검증, 모형 조율 및 지표 세부화 작업 중에 있다.

이렇듯 보편화되고 있는 논리모형 접근에는 <표 $5>$ 와 같이 몇 가지 장점과 단점이 따른다.

〈표 5〉 논리모형 분석 접근의 장점과 단점

제I장

- 정보 공유 : 프로젝트/프로그램 전 과정에서 관련 직원, 공여자, 수혜자, 이해관계자들에게 정보를 시각적으로 요약하는 유용한 참고자료가 됨.

- 영향과 원인 설명 : 개별적 봉사활동을 장기적 영향(impact)과 연계하고, 이를 통해 직간접적 원인과 효과(cause and effect)를 보여줄 수 있음.

- 일관된 접근과 용어 사용 관련 : 논리모형 분석을 통하여 일관된 접근법과 용어를 사용하는 것은 보다 넓은 차원의 개발 프레임워크에서 봉사활동의 위치를 찾도록 해주며, 또한 파트너/ 공여자가 함께 봉사활동의 장기적 기여에 대해 토론할 수 있도록 도와줌.

- 용어의 전문성 : 논리모형에는 전문용어가 사용되며, 때문에 이용자에게 친숙하지 않음.

- 단순성 : 개개인의 경험을 논리모형 분석에서 사용하는 박스 몇 개로 말끔하게 요약하는 것이 불가능함.

- 예측 가능성 가정 : 모든 프로젝트에서 만일의 사태(contingencies)가 예측될 수 있다고 가정하며, 봉사 활동에서부터, 투입, 목적, 목표까지 예측 가능하고 일직선적이며 논리적으로 단 프로세스가 전개된다고 가정함.

점 - 융통성과 현실 문맥 고려 부족 : 프로젝트 디자인을 융통성 없고 통제적으로 만들 수 있으며, 이는 프로젝트 디자인을 현지의 현실 및 상황의 변화와 동떨어지도록 함.

- 수혜자 포괄성 부족 : 논리모형 수립 과정에 극소수의 경우에만 수혜자를 포함함.

- 좁은 시야 : 평가자가 논리모형을 수립할 때 세부내용에 초점을 맞추느라 큰 그림을 간과할 수 있음.

- 디자인 부족: 논리모형에는 기초선 데이터가 강조되지 않음.

출처: UNV (2011a) p.11 및 Morra-Imas et al. (2009) p.205 정리 및 재구성

논리모형은 봉사활동의 기획 단계에서부터 영향 수준까지 아우르는 평가 정보를 명시할 수는 있지만, 봉사활동의 궁극적인 영향을 측정하는 도구로는 적절하지 않다. 왜냐하면 봉사활동 자체로는 영향을 생성하기에 역부족이기 때문이다(UNV, 2011a:11). 또한 논리모형은 평가 수행을 위한 도구이지 평가를 대체할 수는 없다(Morra-Imas et al., 2009: 205). 때문에 논리 모형 분석은 봉사활동이 어떻게 단기적, 장기적 개발목표에 기여할 수 있는지를 모색하는 차원 에서만 유용한 모델이라 할 수 있으며, 모형의 실질적 적용을 통한 성과 달성은 별개의 문제라는 점을 명심해야 한다. 


\section{4. 논리모형의 적용}

앞서 명시된 단점에도 불구하고 논리모형을 풀뿌리 수준에서 성공적으로 적용하는 경우, 봉사 단원과 지역사회 리더, 시민사회 조직이 함께 협력하여(예: 참여적 워크숍 개최 등) 봉사활동 사업계획에 대한 공동 비전을 마련하는데 용이할 수 있다(UNV, 2011a:11). 즉, 논리모형 분석의 제약점을 보완하기 위해서는 참여적 프로세스가 중요한 것이다. 특히 UNV의 경우, 봉사활동 평가에 있어서 논리모형 분석 접근에 기반을 둔 참여적 평가방법을 강조하고 있다(<표 $6>$ 참고).

\section{〈표 6〉참여적 평가(participatory evaluation)}

\begin{tabular}{|c|c|}
\hline $\begin{array}{c}\text { 목적 및 } \\
\text { 특징 }\end{array}$ & 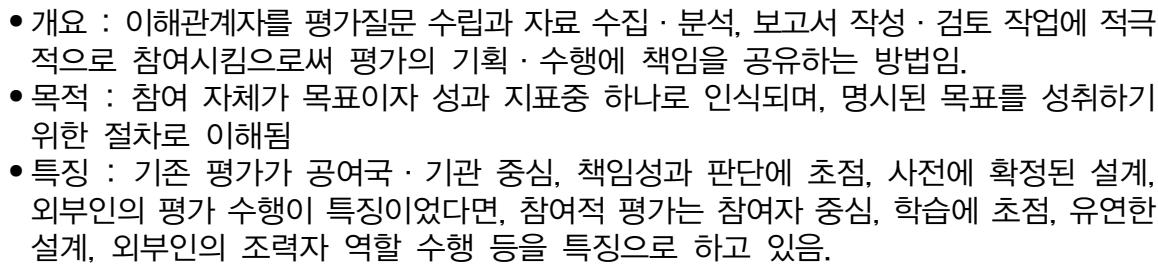 \\
\hline $\begin{array}{l}\text { 기본 } \\
\text { 원칙 }\end{array}$ & $\begin{array}{l}\text { - 목표 설정, 우선순위 결정, 질문 선택, 데이터 분석, 정책 결정 등의 절차에 프로젝트 } \\
\text { 참가자를 참여시킴. 예를 들어, 논의와 합의를 통해 데이터 수집 지침을 수립함. } \\
\text { - 참가자들이 직접 의사결정에 참여하고 결론을 도출함으로써 평가에 대한 주인의식 및 } \\
\text { 책무성을 공유함. 외부 조력자(facilitators)는 필요시 도움을 주는 역할을 수행함. } \\
\text { - 참가자들이 중요시하는 밥법 및 결과에 초점을 맞추어 평가가 진행되도록 함. } \\
\text { - 참가자들이 협력하여 그룹 내 조화를 증진함. } \\
\text { - 평가의 모든 측면을 참가자들이 이해할 수 있고 유의미하도록 함. }\end{array}$ \\
\hline
\end{tabular}

출처: Morra-Imas et al.(2009) p.232-4 요약 및 재구성

참여적 연구는 봉사단원이 아닌 수혜자 및 지역 이해관계자를 주축으로 하는 성과 데이터 수집에 가장 많이 이용되는 방법 중 하나이다. 이때 프로그램 평가전문가는 정부, 비정부기구 (Non-Governmental Organization, 이하 NGO), 지역사회, 프로그램 수혜자 등을 포함하여 광범위한 이해관계자가 적극적으로 정보공유를 하도록 독려하는 역할을 하며, 이를 통해 프로그 램 설계, 이행, 성과 측정에 이해관계자의 피드백, 제안, 지역의 관점을 반영하도록 지원한다. 때문에 참여적 연구는 봉사 프로그램이 현지 지역사회에 진정으로 기여하는 점에 대하여 다각도 의 통찰을 얻는데 효과적일 수 있다(Lough et al., 2015:20).

예컨대 UNV는 Forum(International Forum for Volunteering in Development)9)과 공동으로 참여적 워크솝(participatory workshop)을 실시하여, 해외봉사의 기여를 평가하는 참여적 방법에 대하여 봉사단원과 관리자들을 위한 핸드북·을 제작한 바 있다.10) 동 참여적

9) 해외봉사단 파견기관들의 글로벌 네트워크이며 국제봉사협력기구(International Volunteering Cooperation Organizations, IVCO) 연례총회 개최를 담당하는 조직이다. 전 세계 약 30 개의 해외봉사단 파견기관들을 회원으로 두고 있다. KOICA는 2013년 정회원으로 가입, IVCO 총회(2017.10.22.-10.25)를 서울에서 개최할 예정이다. 
워크숍 실시와 핸드북 제작을 위해서 12 개국의 국내외 봉사단 조직을 포함하여 각종 수혜자 및 파트너기관, 정부, 해외봉사단 파견기관 관계자들이 파일럿 연구에 대거 참여하는 노력을 하였다. 아래 ‘논리모형' 표는 파일럿 연구에 참여한 봉사단원들에 의해 개발되었으며, 봉사단 프로그램 개발에 대한 논의의 기초자료로 활용할 수 있다(UNV, 2011a:11).

〈표 7〉 개발성과 달성을 위한 봉사활동 논리모형

\begin{tabular}{|c|c|c|}
\hline 수준(level) & 설명 & 목적 (objectives) 예시 \\
\hline $\begin{array}{l}\text { 목표 } \\
\text { (goal) }\end{array}$ & $\begin{array}{l}\text { 통제가 불가능한 고차원적인 } \\
\text { 영향력 }\end{array}$ & $\begin{array}{l}\text { - 특정 분야(보건, 교육 등) 혹은 범분야(성 평등, 거버넌스 } \\
\text { 등)에서 글로벌 개발목표에 기여 }\end{array}$ \\
\hline $\begin{array}{c}\text { 의도 } \\
\text { (purpose) }\end{array}$ & $\begin{array}{l}\text { 국별 프로그램으로의 장기적 } \\
\text { 기여, 즉 봉사활동의 누적된 } \\
\text { 영향력 }\end{array}$ & $\begin{array}{l}\text { - 특정분야(보건, 교육 등) 혹은 범분야(성 평등, 거버넌스 } \\
\text { 등)에서 국가의 개발목표에 기여 }\end{array}$ \\
\hline & & 변화의 예시 \\
\hline $\begin{array}{l}\text { 결과 } \\
\text { (outcomes) }\end{array}$ & $\begin{array}{l}\text { 파트너십을 통해 생기는 보다 } \\
\text { 넓은 변화(행동변화) }\end{array}$ & $\begin{array}{l}\text { - 사람들의 삶에 변화 (예: 경제적, 문화적, 개인적, 사회 } \\
\text { 적, 심리적 변화) } \\
\text { - 젠더 및 권한 관계의 변화 } \\
\text { - 태도, 아이디어, 의식, 행동의 변화 } \\
\text { - 집단, 지역사회, 조직 및 제도적 변화(예: 실행, 행동, 우 } \\
\text { 선순위, 자원, 체계 등의 변화) } \\
\text { - 다양한 범위 이해관계자의 지속적 참여, 커미트먼트, 지원 } \\
\text { - 수원기관의 자립성 개발 } \\
\text { - 시민사회와 정부 간의 개방적 대화와 신뢰 개발 } \\
\text { - 봉사홛동의 가치에 대한 태도 변화 } \\
\text { - 여성의 임파워먼트 및 여성의 기여에 관한 인정 } \\
\text { - 조직의 강화 } \\
\text { - 서비스 전달의 향상 } \\
\text { - 새로운 체계 시행(예: 정부 프로그램) } \\
\text { - 파일럿 프로젝트의 확장 } \\
\text { - 사회적 이슈, 경제적 이슈, 친빈곤(pro-poor) 정책에 대 } \\
\text { 한 인식 제고 } \\
\text { - 분쟁 감소 }\end{array}$ \\
\hline $\begin{array}{l}\text { 산출물 } \\
\text { (outputs) }\end{array}$ & $\begin{array}{l}\text { 단원의 행동으로 인한 직접 } \\
\text { 적 · 구체적인 결과(results) } \\
\text { (생산되거나 전달된 물품 } \\
\text { 서비스) }\end{array}$ & $\begin{array}{l}\text { - 교육을 받는 여성/남성/청소년의 수 등 } \\
\text { - 시스템의 강화 및 구축 } \\
\text { - 파트너십 구축 건수 } \\
\text { - 설립된 학교의 수 } \\
\text { - 출판된 문서/간행물의 수 }\end{array}$ \\
\hline $\begin{array}{c}\text { 활동 } \\
\text { (activities) }\end{array}$ & $\begin{array}{l}\text { 단원이 하는 행동 } \\
\text { (재정 - 인적 자원 등의 투입 } \\
\text { 물을 산출물로 변화시키기 위 } \\
\text { 해 수행한 행동) }\end{array}$ & $\begin{array}{l}\text { - 역량 강화 } \\
\text { - 기술자문 } \\
\text { - 동원 } \\
\text { - 네트워킹 } \\
\text { - 옹호 } \\
\text { - 연구 }\end{array}$ \\
\hline
\end{tabular}

출처: Binneydijk (2000) p.20; UNV (2011a) p.11; Haddock and Devereux (2015) p.38에서 재인용

10) UNV 홈페이지 및 보고서를 참조하기 바란다. (https://www.unv.org/news/) (접속일: 2016.11.25.) 
위의 논리모형에 의하면, 산출물과 단원의 활동은 엄밀하게 말하면 성과에 해당되지 않는다 (Binneydijk, 2000). 예를 들어, WFK 단원들이 개도국에 기술자문 제공이나 역량 강화 활동을 수행했다고 해서, 그 자체를 WFK 사업의 성과라고 내세울 수는 없는 것이다. 마찬가지로 단원의 이니셔티브로 인해 현지에 설립된 학교의 수, 한국어 교육을 받은 개도국 주민의 인원, 단원이 발간한 간행물 출판 건수 등의 산출물도 WFK 사업의 성과로 내세울 수 없다. 간단한 활동과 산출물 수준에서 더 나아가, 사람들의 삶과 태도, 지역사회의 자립성, 현지 기관의 기술 및 현지 정부의 제도에 나타난 보다 광범위한 변화를 입증하는 것이 바로 해외봉사 사업으로 인한 진정한 개발 성과로 인정될 수 있는 것이다.

아래 <표 8>은 상기 논리모형을 적용하여 실제로 측정이 가능한 변화, 즉 결과(results/ outcomes) 수준의 성과 요소 예시(pool)를 보여준다. 참고로, 아래 명시한 요소들은 봉사단원 들이 관찰한 변화를 중심으로 나열한 것이다.

〈표 8〉 측정이 가능한 결과 수준 성과 요소(변화) 예시

\begin{tabular}{|c|c|c|}
\hline 이해관계자 & 변화 측면 & 요소 예시(pool) \\
\hline 봉사단원 & $\begin{array}{l}\text { 개인적, 사회적 } \\
\text { 변화 }\end{array}$ & $\begin{array}{l}\text { - 범문화적 이해 증진 } \\
\text { - 전통적 지식에 대한 가치 인정 } \\
\text { - 기술의 개발 } \\
\text { - 글로벌 교육에 대한 커미트먼트 }\end{array}$ \\
\hline \multirow{2}{*}{$\begin{array}{l}\text { 수원 기관 } \\
\text { (Host } \\
\text { organization) }\end{array}$} & 태도 및 접근 & $\begin{array}{l}\text { - 기술자에게서 관찰되는 태도의 변화 (예: 하향식/top-town 업무 } \\
\text { 지시가 감소하는 대신, 참여적 접근의 증가) }\end{array}$ \\
\hline & 조직의 개발 & - 업무에 관련된 관행과 문화 변화 \\
\hline \multirow[t]{2}{*}{$\begin{array}{l}\text { 지역사회 } \\
\text { 구성원/ } \\
\text { 시민사회 }\end{array}$} & 자조/자립 & $\begin{array}{l}\text { - 지역사회 간의 연계를 통해 지역개발 계획을 위한 파트너십 관련 } \\
\text { 새로운 아이디어 도출 } \\
\text { - 마을 주민이 더 이상 UNV가 문제를 해결해주기만을 기다리지 } \\
\text { 않고, 자립에 대해 새로운 태도와 사고방식 도출 }\end{array}$ \\
\hline & 포함 (Inclusion) & $\begin{array}{l}\text { - 마을 간 토지 운영을 위한 위원회에서 여성의 참여와 여성의 공식 } \\
\text { 적 역할이 증가 }\end{array}$ \\
\hline 지역 NGO & 기술 & - 역량 강화로 인해서 여성 집단의 프로젝트 계획 기술 향상 \\
\hline 벽정부 & 관계 & - 시민사회와 국회의원(elected officials) 간의 신뢰도와 인정 증가 \\
\hline \multirow{2}{*}{ 민간부문 } & 민-관 파트너십 & - 마을 학교를 위해 컴퓨터 기술 훈련 제공에 대한 커미트먼트 증가 \\
\hline & 책임과 우선순위 & - 항레트로바이러스(antiretroviral) 약물 가격을 저가로 유지 \\
\hline 미디어 & 커뮤니케이션 & - 지역 라디오 프로그램이 보건교육을 홍보 \\
\hline 국가의 정부 & $\begin{array}{l}\text { 태도, 우선순위, } \\
\text { 제도적 개발 }\end{array}$ & $\begin{array}{l}\text { - 시민사회가 개발에 참여하도록 환경 조성(법적 프레임워크 등 이용) } \\
\text { - 국가적/지역적 봉사활동이 개발을 위한 수단(means)이라는 점 }\end{array}$ \\
\hline
\end{tabular}




\begin{tabular}{|c|c|c|}
\hline 이해관계자 & 변화 측면 & 요소 예시(pool) \\
\hline & & $\begin{array}{l}\text { 을 인정 } \\
\text { - 봉사활동의 가치를 인정 및 이를 응용 } \\
\text { - 지역 봉사단원의 니즈와 역량 조사 } \\
\text { - 지역의 보건 이니셔티브를 향한 여성의 자발적 기여에 대한 인정 } \\
\text { - 국가 봉사활동 관련 조직 생성 }\end{array}$ \\
\hline $\begin{array}{l}\text { 국제적 } \\
\text { 파트너기구 }\end{array}$ & 태도 및 접근 & $\begin{array}{l}\text { - 봉사활동을 프로그램에 주류화(mainstreaming) } \\
\text { - 개발에 있어서 봉사활동의 특유 가치(added value)에 대한 인식 } \\
\text { 제고 }\end{array}$ \\
\hline $\begin{array}{l}\text { 공여국/ } \\
\text { 공여기관 }\end{array}$ & 커미트먼트 & - 봉사활동에 대한 인정 및 지원 증가 \\
\hline 현지의 대중 & $\begin{array}{l}\text { 관계, 의식, } \\
\text { 커미트먼트 }\end{array}$ & $\begin{array}{l}\text { - 개발에 참여하고자 하는 동기 증가 } \\
\text { - 더 넓은 세계와 연계되어 있다는 느낌 증가 }\end{array}$ \\
\hline
\end{tabular}

출처: UNV (2011a) p.12 저자가 재구성

위의 표에서 보다시피, 봉사활동으로 인하여 측정 가능한 변화 및 결과에는 여러 가지가 있는데, 그 요소들을 보면, '커미트먼트', '이해 증진', '문화 변화'와 같은, 간단한 수치로는 측정 하기 쉽지 않은 요소들이 포함되어있다. 또 다른 종류의 개발사업과는 달리 해외봉사는 다양한 인적, 자본적, 관계적 요소가 포함된 복잡한(messy) 성격의 사업인 점을 고려했을 때, 위의 표가 명시하는 변화가 봉사단원들의 활동으로 인한 결과라는 것을 어떻게 견고히 증명할 수 있을지 의문도 들 수 있다.

예를 들어, $\mathrm{WFK}$ 봉사단 파견으로 인해 개도국 수원기관의 관행과 문화가 업무에 긍정적인 방향으로 개선되었음을 확인했을 때, 이것이 WFK 봉사단원의 활동으로 인한 것인지, 혹은 수원기관이 동시에 직원들에게 별도로 업무향상 훈련을 시행함으로써 초래된 결과인지 인과관 계를 규정짓기에는 어려움이 있다. 때문에 결과 수준의 변화를 측정하고 해석할 때는 봉사단원 의 활동뿐 아니라 수원기관과 현지 주민 측의 문맥도 고려해야 한다. 이러한 점을 보완하는 차원에서 UNV는 삼각측량법(triangulation)의 활용을 강조하고 있다(UNV, 2011a:13).

\section{5. 삼각측량법}

삼각측량법은 데이터의 정확도를 향상시키고자 다양한 방법으로 정보를 수집하는 것을 말한 다. 평가 수행자는 평가 결과의 입지를 강화하기 위해 삼각측량법을 활용하는데, 다양한 방법을 통해 결과를 입증하는 정보를 수집할수록 증거가 보다 확고해진다(Morra-Imas et al., 2009:355). 삼각측량법은 즉 다양한 이해관계자와 함께 정보와 조사 결과를 대조검토(crosscheck) 하는 프로세스이자, 평가 분석의 품질 향상을 위해 다양한 문맥과 정보의 출처를 고려한 
다각적 프로세스라 할 수 있다. 따라서 성과 측정의 견고성과 신뢰성을 보다 잘 보장하며, 해외 봉사 M\&E에 관련하여 다양한 수준에서의 교훈 도출을 가능케 해준다(UNV, 2011a:13).

삼각측량법을 통해 도출한 조사 결과와 교훈은 전략적 계획과 향후 사업 운영에 반영되어야 하며, 이해관계자와도 공유되어 환류(feedback) 과정에 포함될 수 있도록 해야 한다. 특히 현지 환류 과정에 포함될 수 있도록 현지어로도 소통되어야 한다(UNV, 2011a:13).

$\mathrm{WFK}$ 의 경우 성과 평가 시 삼각측량법을 적용하여 1) 수원국 기관 측면, 2) 봉사활동 수혜자 (수원국 주민) 측면, 3) 단원 측면 등에서 활동 정보와 데이터를 수집함으로써 성과 측정의 객관성과 신뢰도를 확고히 할 수 있을 것이다.

위의 섹션에서는 해외봉사 사업의 성과 측정 동향을 분석하고 성과 측정의 이론적 접근에 대해 전반적으로 탐구해보았다. 이하 섹션에서는 보다 세부적으로 해외봉사 성과를 SDGS와 연계하여 측정하는 방법과 도전과제에 대해 분석하고자 한다.

\section{SDGs 달성을 위한 측정}

\section{1. 해외봉사단의 SDGs 기여 측정 현황}

현재 2030 지속가능개발 어젠다는 SDGs의 17 개 목표와 169 개 세부 목표, 그리고 241 개의 지표로 이루어져있는데, 이 수많은 지표의 이행수단으로 강조되는 영역 가운데 하나가 바로 통계를 활용한 모니터링이다(UN, 2015). 동시에 UN은 봉사활동이 SDGs 달성을 위한 강력한 범분야적 이행수단(Powerful Cross-cutting Means of Implementation)으로서, SDGs 달 성에 필요한 교육, 보건, 농업, 거버넌스, 경제 등의 분야에 직간접적으로 기여할 수 있음을 인정하고 있다(UNV, 2015). 그럼에도 불구하고 최근 2016년 3월 제시된 SDGs 지표에 봉사활 동과 봉사활동 측정이나 지표에 대해 명시하지 않고 있는 점11)은 SDGs 체계 내에서 봉사활동 의 가시성 향상에 보다 노력이 필요하다는 점을 암시한다.

예컨대, WFK도 현재 파견 인원, 인적정보, 활동영역 등의 간단한 데이터를 기본적으로 수집·기록하는 체계는 갖추고 있으나, 중장기 성과지표 수립이나 성과의 SDGs 연계에 대해서

11) UN IAEG 홈페이지를 참조하기 바란다. (http://unstats.un.org/sdgs/indicators/indicators-list/) (접속일: 2017.1.2.) 
는 현재 실행 가능한 전략을 모색하는 단계에 있다. 그러나 비단 WFK 뿐만이 아니라 전 세계 대부분의 해외봉사단도 기존 성과 측정과 글로벌 개발의제 간의 연계에 불분명한 진척도를 보이고 있는 것은 사실이다.

이처럼 국제사회가 봉사활동의 성과 측정에 대한 중요성은 인식하고 있으나, 아직 측정을 위한 실질적인 실천이 부족하다는 점은 많은 해외봉사단 파견기관이 공감하는 부분이기도 하다. 특히 봉사단의 글로벌 개발의제 달성도 측정이 어려운 이유는 다양한 봉사단체 간의 조율 부족, $\mathrm{V} 4 \mathrm{D}$ 및 봉사에 대한 지나치게 다양한 정의와 개념, 봉사활동 관련 데이터의 일관성과 통일성 부족, 기여(contribution)에 대한 개념의 모호성, 측정을 위한 자금 부족 및 자금 출처의 모호성 등이라 지적된다(Haddock, 2016).

이러한 어려움의 해결 방안으로 $\operatorname{Haddock(2016)ㅇㅡㄴ~ㄱㅜㄱㄱㅏㅈㅓㄱㅇㅡㄹㅗ~ㅌㅗㅇㄱㅖ~ㄱㅣㅊㅗㅅㅓㄴ(baseline)~ㅈㅏㄹㅛ~}$ 를 보다 많이 구축할 것을 제안하고 있으며, 동시에 지역사회 수준에서의 정보· 데이터 수집 필요성을 강조하고 있다. 이를 위해 해외봉사 파견기관이 시행 가능한 조치로는 봉사활동 측정 현황에 대한 정보를 국가통계청(National Statistics Office)에 주기적으로 문의하고 봉사활동 통계정보 수집을 위한 지침을 제공할 것, 국내 봉사 인프라 관련 기관과 협력을 통하여 인프라 관련 정책과 측정을 옹호할 것, 국제연합(United Nations, 이하 UN) 고위급정치포럼(High Level Political Forum, 이하 HLPF)에서 봉사활동 관련 목소리를 강화할 것, 봉사활동 관련단 체들이 협업 및 소집할 수 있는 장소(convening space)를 제공할 것, 데이터 플랫폼 개발을 통해 집에서도 컴퓨터로 쉽게 봉사 관련 정보 검색이 가능토록 지원할 것, 봉사활동 측정 관련 연구와 옹호를 위해 기금을 지원할 것, UN 기관 및 $\mathrm{HLPF}$ 등에서 주목을 받기 위해 간결하고 설득력 있는 보고서를 작성하고 행사를 주최할 것, 봉사활동의 기여에 대해 분명하게 표현하고 보고할 것을 권장한다.

\section{Mapping 모델}

SDGs에 대한 해외봉사활동의 기여를 기록(document)하고 증명하기 위해서는 SDGs와 봉사활동 성과 간 분명한 연계가 필요하다. 이에 따라 해외봉사단 파견기관은 기존 봉사 사업의 목적이 SDGs와 어떻게 연계될 수 있는지를 모색해야 한다. 이를 위해서 Haddock. Devereux(2015)는 해외봉사와 SDGs 간의 mapping 모델을 제시한바 있다.

Haddock and Devereux(2015)의 mapping 은 상당수의 봉사활동이 SDGs 중 하나에 직접 적으로 연계될 수 있다는 점에 초점을 맞춘다. 예를 들어, 개도국 학교 교사를 대상으로 실시하 
는 교육 역량 강화 훈련 활동은 SDG 네 번째 목표인 양질의 교육 제공에 확실히 기여할 수 있다(<표 9> 참고).

〈표 9〉봉사활동 (교사에게 훈련 제공)과 SDG 4(양질의 교육) 간의 연계

\begin{tabular}{|c|l|}
\hline \multicolumn{1}{|c|}{ 봉사활동 내용 } & \multicolumn{1}{c|}{ SDG 4(양질의 교육) } \\
\hline 학교의 교사들에게 훈련을 제공한다. & $\rightarrow \begin{array}{l}\text { 모든 사람에게 포괄적이며 공평한 양질의 교육을 } \\
\begin{array}{l}\text { 보장하고, 모든 이의 전 생애에 걸쳐 교육의 기회를 } \\
\text { 촉진한다. }\end{array}\end{array}$ \\
\hline
\end{tabular}

출처: Haddock and Devereux (2015) p.32의 표를 저자가 재구성

더 나아가, 봉사 프로그램의 다양한 요소와 활동은 SDGs의 목표에 동시다발적으로 기여하며 시너지효과를 낼 수도 있다(Haddock·Devereux, 2015:32). 예컨대, 봉사단원의 활동이 워크 솝 및 스포츠 활동을 통하여 특수아동 지도교사에게 기술과 자문을 제공할 경우, 교사에 대한 훈련은 교육뿐만 아니라 빈곤퇴치, 여성의 권한 강화(훈련받은 교사들이 여성일 경우), 불평등 완화(교육 소외계층에게 필요 기술을 제공하여 빈곤을 개선), 양질의 일자리 창출(훈련을 통해 새로운 고용 기회가 생성된 경우), 파트너십 개발 및 강화(교육부 등의 기관과 협력한 경우)에도 함께 기여하게 된다.

〈표 10〉 봉사활동과 SDGs 간의 연계 Mapping

\begin{tabular}{|l|l|l|}
\hline \multicolumn{1}{|c|}{ 봉사활동 내용 } & \multicolumn{1}{|c|}{ SDGs } \\
\hline 워크숍 및 스포츠를 통하여 특수아동 지도교 & $\rightarrow$ & SDG 1: 빈곤 퇴치 \\
사에게 기술 지원과 자문 & SDG 4: 양질의 교육 \\
SDG 5: 양성 평등 \\
SDG 8: 일자리와 경제성장 \\
SDG 10: 불평등 완화 \\
SDG 17: 이행수단 및 파트너십 강화
\end{tabular}

출처: Haddock and Devereux (2015) p.33의 표를 저자가 재구성

위의 mapping 은 다시 아래의 <표 $11>$ 와 같이 더욱 세부적인 목표 수준으로 나누어서 mapping할 수 있다. 
〈표 11〉봉사활동과 SDGs 목표·세부 목표 간의 Mapping

\begin{tabular}{|c|c|c|}
\hline 봉사활동 내용 & & SDGs \\
\hline \multirow{12}{*}{$\begin{array}{l}\text { 워크숍 및 스포츠를 } \\
\text { 통하여 특수아동 지도 } \\
\text { 교사에게 기술 지원과 } \\
\text { 자문 }\end{array}$} & \multirow{12}{*}{$\rightarrow$} & $\mathrm{SDG} 1$ : 빈곤 퇴치 \\
\hline & & - 목표 1.5 취약 환경 및 빈곤계층을 위한 회복 역량 구축 \\
\hline & & SDG 4: 양질의 교육 \\
\hline & & $\begin{array}{l}\text { - 목표 } 4.5 \text { 모든 수준의 교육 및 직업 훈련에 대한 취약계층의 동등한 } \\
\text { 접근성 확보 } \\
\text { - 목표 4.a 아동, 장애, 젠더 민감성을 고려한 교육시설 구축 및 개선 } \\
\text { - ․․ 자격 있는 교사의 양적 확대 }\end{array}$ \\
\hline & & $\mathrm{SDG}$ 5: 양성 평등 \\
\hline & & $\begin{array}{l}\text { - 목표 } 5.5 \text { 여성의 완전하고 효과적인 참여 및 지도층에 대한 동등한 기회 } \\
\text { 보장 }\end{array}$ \\
\hline & & $\mathrm{SDG}$ 8: 일자리와 경제성장 \\
\hline & & $\begin{array}{l}\text { - 목표 } 8.5 \text { 완전하고 생산적인 고용 창출 및 청년과 장애인을 포함 모든 } \\
\text { 인구에 대한 양질의 일자리 제공 } \\
\text { - 목표 } 8.6 \text { 비고용, 비교육, 비훈련된 청년 비율을 대폭 감소 }\end{array}$ \\
\hline & & SDG 10: 불평등 완화 \\
\hline & & - 목표 10.2 모든 사람들의 사회적, 경제적, 정치적 포괄성 및 권한 강화 \\
\hline & & SDG 17: 이행수단 및 파트너십 강화 \\
\hline & & $\begin{array}{l}\text { - 목표 } 17.16 \text { 다양한 이해관계자 간의 글로벌 파트너십 강화로 지식, 전 } \\
\text { 문성, 기술, 재정 자원의 공유 및 동원을 통해 모든 국가, 특히 개도국 } \\
\text { 내 지속가능한 개발에 기여 }\end{array}$ \\
\hline
\end{tabular}

출처: Haddock and Devereux (2015) p.33의 표를 저자가 재구성

상기 <표 $11>$ 은 특정 봉사활동 요소가 SDGs의 어떤 목표와 세부 목표에 기여하는지를 명백히 보여준다. 더 나아가 상기 mapping을 SDGs 달성을 위한 투입, 산출물, 결과, 영향에 대한 논리모형으로 발전시킬 수 있다. 예를 들어, 아래의 표는 두 가지 종류의 봉사활동이 SDG 16 불평등의 완화에 어떻게 기여하는지 명시한다. 
〈표 12〉 봉사활동의 SDG 16 기여 mapping 논리모형

\begin{tabular}{|c|c|c|}
\hline \multicolumn{3}{|c|}{$\begin{array}{l}\text { 지속가능발전을 위해 평화롭고 포용적인 사회를 증진하고, 모두가 정의에 접근할 수 있도록 하며, } \\
\text { 모든 수준에서 효과적이고 책임성 있는 포용적인 제도를 구축한다. }\end{array}$} \\
\hline $\begin{array}{r}\begin{array}{r}\text { 봉사활동 } \\
\text { 내용 }\end{array} \\
\text { 논리모형 }\end{array}$ & 지역사회 분쟁조정 서비스 제공 & $\begin{array}{c}\text { 여성을 위한 옹호전략 및 정치참여 } \\
\text { 훈련 제공 }\end{array}$ \\
\hline 파트너십 구축 & $\begin{array}{l}\text { - 정부 } \\
\text { - 비영리단체 } \\
\text { - 사기업 }\end{array}$ & $\begin{array}{l}\text { - 정부 } \\
\text { - 비영리단체 } \\
\text { - 사기업 }\end{array}$ \\
\hline $\begin{array}{l}\text { 해외봉사 고유의 } \\
\text { 기여/성과 }\end{array}$ & $\begin{array}{l}\text { - 다양한 이해관계자들 간의 연계구 } \\
\text { 축, 문제 해결 성과 모니터링 }\end{array}$ & - 풀뿌리 수준에서 목소리 촉진 \\
\hline $\begin{array}{l}\text { SDGs와 연계 } \\
\text { mapping }\end{array}$ & $\begin{array}{l}\text { - 목표 } 5 \text { (성평등) } \\
\text { - 목표 } 10 \text { (불평등 감소) }\end{array}$ & $\begin{array}{l}\text { - 목표 } 1 \text { (빈곤퇴치) } \\
\text { - 목표 } 5 \text { (성평등) } \\
\text { - 목표 } 4 \text { (양질의 교육) }\end{array}$ \\
\hline 영향 & $\begin{array}{l}\text { - 평화적 분쟁해결에 접근 가능한 사 } \\
\text { 람 수가 } 83 \% \text { 증가 } \\
\text { - 귀국봉사단원이 } \$ 20 \mathrm{k} \text { 재정 동원 } \\
\text { - 정책 변화 달성 }\end{array}$ & $\begin{array}{l}\text { - 공적 영역에 참여하는 여성 수 } 60 \% \\
\text { 증가 } \\
\text { - 정책결정자의 여성 역할 증대에 관하 } \\
\text { 여 관심 증대 }\end{array}$ \\
\hline $\begin{array}{c}\text { 결과 } \\
\text { (프로그램 성과 내용) }\end{array}$ & $\begin{array}{l}\text { - } 250 \text { 개 사례에서 평화로운 방법으로 } \\
\text { 문제 해결 } \\
\text { - 봉사단원의 기술, 역량, 자신감 향상 } \\
\text { 에 따른 새로운 역할 채택 } \\
\text { - 귀국단원의 파트너 지원 통해 정책 } \\
\text { 변화 위한 자원신청/로비 }\end{array}$ & $\begin{array}{l}\text { - } 3,000 \text { 명의 여성이 훈련에서 배운 기 } \\
\text { 술을 사용했다고 보고 } \\
\text { - 배운 기술을 타인과 공유 }\end{array}$ \\
\hline $\begin{array}{c}\text { 산출물 } \\
\text { (서비스 수혜자 수, } \\
\text { 지원된 서비스· 물품 수) }\end{array}$ & $\begin{array}{l}\text { - 서비스 수혜자 } 800 \text { 명 } \\
\text { - 분쟁조정 사례 } 300 \text { 건 } \\
\text { - } 25 \text { 개의 공동체가 서비스를 수혜 } \\
\text { - } 4 \text { 개의 개도국이 서비스를 수혜 }\end{array}$ & $\begin{array}{l}\text { - } 5,000 \text { 명의 가난한 여성이 훈련을 수혜 } \\
\text { - } 50 \text { 개 공동체가 훈련을 수혜 } \\
\text { - } 7 \text { 개 국가에서 훈련을 수혜 }\end{array}$ \\
\hline $\begin{array}{l}\text { 투입 } \\
\text { (수원국) }\end{array}$ & $\begin{array}{l}\text { - 50명의 지역봉사단원 투입 } \\
\text { - 500시간 투입 }\end{array}$ & $\begin{array}{l}\text { - } 10 \text { 명의 지역봉사단원 투입 } \\
\text { - } 150 \text { 시간 투입 }\end{array}$ \\
\hline $\begin{array}{l}\text { 투입 } \\
\text { (공여국) }\end{array}$ & $\begin{array}{l}\text { - } 2 \text { 명의 해외봉사단원 투입 } \\
\text { - } 200 \text { 시간 투입 } \\
\text { - } \$ 5,000 \text { 비용 발생 }\end{array}$ & $\begin{array}{l}\text { - } 6 \text { 명의 해외봉사단원 투입 } \\
\text { - } 100 \text { 시간 투입 } \\
\text { - } \$ 1,500 \text { 비용 발생 }\end{array}$ \\
\hline
\end{tabular}

출처: Haddock and Devereux (2015) p.43 재구성

상기 mapping 모델을 활용함으로써 여러 가지 장점을 얻을 수 있는데, 이는 1) SDGs를 향한 기여를 기관별로 특성화하여 보여주도록 유연성 제공, 2) SDGs를 향한 기여를 국가. 국제 적 차원에서 보고(reporting)하도록 기회 제공, 3) SDGs 목표(goal)·세부 목표(target) 수준 에서 보고하는 방법 제공, 4) 기존 정보를 활용하여 여러 수준에서 세부 성과를 보고하도록 유연성 제공, 5) 양적·질적 정보를 수집하는 메커니즘 제공, 6) 성과 보고뿐 아니라 지역사회 
이해관계자를 위해 배움과 권한 강화 기회 제공, 7) 국제·국내·지역 파트너와의 공동성과를 도출하여 이를 인정하는 기회 제공 등을 포함한다(Haddock·Devereux, 2015:44).

상기 mapping 모델이 세부적 봉사 활동(activities)을 SDGs의 세부 목표에 자동적으로 연계시키는 툴을 통해 저절로 완성되는 체계가 된다면 가장 이상적일 것이다. 또 어떤 활동을 보고할 것인지에 대해서도 옵션을 제공하는 드롭다운(drop-down) 메뉴를 활용할 수도 있다. 예를 들어, 일반적 봉사활동에 대한 성과 보고를 선택하거나, 아니면 일반적 옵션에 속하지 않은 활동을 '기타' 옵션(예: 봉사활동을 제외한 활동으로서, 단원 자비를 이용한 지역사회 성교 육 캠페인 지원 등)으로 입력하도록 할 수 있다. 덧붙여서, 특정한 질적(qualitative) 투입물에 대한 링크를 클릭할 수 있도록 함으로써 해당 투입물에 대한 상세한 정보, 사진, 비디오 등을 열람할 수 있도록 하는 기술도 가미할 수 있다(Haddock·Devereux, 2015:44).

제I장

이처럼 상기 mapping 모델은 유연성이 높아서 그 기능을 잘 개발하고 활용하면 WFK 사업의 개발성과 측정과 지표 수립에도 유용한 툴이 될 가능성이 높다. 예를 들어, WFK 사업이 집중하고 있는 영역인 교육(예: SDG 4), 보건(SDG 3), 공공행정(SDG 16), 산업에너지(SDG 9,11 등), 농림수산(SDG 14, 15 등) 등의 분야별로 구분하여 SDGs 연계 mapping 모델을 설계함으로써, 개발성과를 전략적으로 측정하고 분석할 수 있을 것이다. 보다 자세한 방법에 대해서는 추후 섹션에서 보다 상세히 논의키로 하겠다.

앞서 우리는 해외봉사의 가치측정에 관하여 비용효과성 환산 접근법, $\mathrm{M} \& \mathrm{E}$ 접근법, 변화이론 (논리모형), 그리고 SDGs와의 연계 모형 등의 주요 접근법에 관하여 알아보았다. 아래 섹션에 서는 이러한 접근법을 포함하여 해외봉사 측정에 관련한 전반적 비판과 도전과제를 자세히 알아보겠다.

\section{V. 도전과제}

해외봉사 성과 측정의 보편적 이론 부족과 우수사례 부족은 앞서 알아보았듯이 해외봉사의 영향을 증명하는 작업이 쉽지 않다는 점을 보여준다. 아래 <표 $13>$ 은 해외봉사 사업을 비롯한 국제개발사업의 $\mathrm{M} \& \mathrm{E}$ 에 있어서 빈번한 문제점을 정리하여 보여준다. 
〈표 13〉 국제개발사업의 모니터링과 평가(M\&E)에 대한 전반적 문제점 요약

\begin{tabular}{|c|c|}
\hline 비판 주안점 & 내용 \\
\hline 구체적 목표 부족 & M\&E가 무엇을 위한 것인지에 대한 구체적 설정 부족 \\
\hline 이해관계자 참여 부족 & 이해관계자의 참여 부족 혹은 대응 부족 \\
\hline 이론 활용 부족 & $\begin{array}{l}\text { 변화이론에 대한 관심 부족, 즉, 투입물(inputs)과 산출물(outputs)에 대한 } \\
\text { 지나친 초점이 맞추어지는 반면, 결과물(outcomes)에 대한 초점 부족 }\end{array}$ \\
\hline 역량 부족 & M\&E에 대한 체계적 역량 구축의 부족 \\
\hline 자원 투입 부족 & $\begin{array}{l}\text { 타깃 그룹/인구의 웰빙/삶의 질 변화에 있어서 특정 프로그램이 어떻게 } \\
\text { 기여하였는지 찾아내기 위함에 있어 자원 투입의 부족 }\end{array}$ \\
\hline 초점 부족 & 영향의 방향 및 향후 궤도(trajectories)에 대한 초점 부족 \\
\hline 맥락 고려 부족 & $\begin{array}{l}\text { 어떤 요소가 왜, 그리고 어떤 상황에서 성과를 가져다주는지에 대한 분석 } \\
\text { 부족 }\end{array}$ \\
\hline 학습 부족 & 융통성과 학습(learning)에 대한 초점 부족 \\
\hline 데이터의 활용 부족 & 평가 결과는 향후 의사결정 프로세스에 적극적으로 환류 되어야 함 \\
\hline
\end{tabular}

출처: Franco and Shahrokh (2012) p.27 저자가 재구성

상기 명시한 문제점 중에서 가장 심각한 문제는 학습의 부족 및 이해관계자의 참여와 대응 부족이다(Franco-Shahrokh, 2012:27). 실제로 M\&E는 대부분의 기관과 조직이 부담스러워 하는 주제가 되어버렸는데, 그 이유는 조직이 $\mathrm{M} \& \mathrm{E}$ 과정에 많은 에너지와 자원을 투입함에도 불구하고, $\mathrm{M} \& \mathrm{E}$ 를 수행함으로써 얻는 학습에는 노력이 부족하기 때문이다. 즉, $\mathrm{M} \& \mathrm{E}$ 수행을 통한 환류 과정이 제대로 작동하지 않는 것이다.

특히 영향력이 없거나 적은 사업에 예산을 배정하는 것은 현실적으로 어려움이 있기에, M\&E 보고서는 대부분 비공개로 처리된다. 또한 $\mathrm{M} \& \mathrm{E}$ 의 품질과 타당성을 검증하는 제 3 자 검토 과정 이 대부분 부재하여 그 설득력이 낮다는 문제도 있으며, 의무적 검토(mandatory donor reviews) 등을 통해 M\&E 결과를 대중에 공개하는 경우 부정적인 검토보고서가 기관에 불리 하게 작용할 가능성을 고려했을 때, 기관이 $\mathrm{M \& E}$ 검토와 결과를 학습의 기회로 수용하는데 주저하는 현상은 어떻게 보면 자연스러울 수 있다(Franco-Shahrokh, 2012:27). 이는 M\&E를 통한 환류와 프로그램 질 향상을 어렵게 하는 요인이 된다. 게다가 $\mathrm{M} \& \mathrm{E}$ 프로세스가 상향식 책무(upward accountability, 예: 공여기관·공여국)에만 집중하며 하향식 책임(예: 수혜자)을 간과하는 성향이 있는데, 다양한 책임소재에 균형을 맞추고 모든 이해관계자의 관심사를 일치시 켜야 할 필요도 있다(Franco·Shahrokh, 2012:28). 
상기 명시된 제약점 외에도, Lough et al.(2015)는 해외봉사의 M\&E에 있어서 향상이 필요 한 영역으로서 해외봉사 프로그램의 구체성, 성과 평가 연구 및 설계, 성과 분석 방법, 측정·평가 도구를 설명하고 있다.

제I장

기여를 한다고 보고한다(Lough et al., 2015:18). 하지만 단원이 해당 영역에서 어떠한 경로로 긍정적 결과를 달성하는지, 혹은 어떻게 보다 효과적인 결과를 초래하는지에 대한 구체적인 분석이 불충분하다. 이는 해외봉사의 효과성이나 개발성과를 설명하는 이론적 틀과 보편적 모형의 부족에서 기인한 것이라 할 수 있다(Lough et al., 2015:18).

만일 긍정적인 결과가 있었다고 해도 해당 결과가 봉사단원에 의해 초래된 것인지 아니면 다른 외부적 요인에 의한 것인지에 대한 인과관계를 명확하게 규정하는 게 어렵다는 문제도 지적된다. 이는 봉사 사업의 수행 프로세스가 복잡하며 해외봉사를 통해 얻고자 하는 성과가 종종 지나치게 거시적이기 때문이기도 하다(Lough et al., 2015:18).

따라서 우선적으로 해외봉사 프로그램과 수행 과정이 세부적으로 구체화되어야 해외봉사단 원으로 인해 초래된 영향과 외부 문맥적 요인(예: 국가정책 변화)으로 초래된 성과 간 분명한 구분이 생길 것이다(Lough et al., 2015:18). 즉, 프로그램 수행 과정을 분명하고 구체적으로 명시함으로써 해외봉사 사업의 효과에 대한 설득력을 높일 수 있다.

\section{2) 연구 및 평가 설계의 한계}

대부분의 해외봉사 성과 보고서를 보면 인과관계 추론이 가능한 연구 설계가 모호한 경우가 많다(Lough et al., 2015:18). 때문에 외부적 요인이 아닌 봉사활동이 개발성과에 기여했다는 확실한 증거를 보여주는 보고서가 전무하다. 소수의 연구에서 장기적인 관찰(longitudinal observations) 방법을 통해 결과를 평가하고 있으나, 무작위할당(random assignment), 준실 험연구(quasi-experimental designs), 비교그룹(comparison groups) 연구와 같이 보다 견 고한 방법론을 통해서 해외봉사 사업의 효과성에 대해 반 사실적/사후 가정 증거(counterfactual evidence)를 제시하는 보고서가 단 하나도 없다는 점은 규탄할 만하다(Lough et al., 2015:18).

동시에 대부분 조사에서는 기초선 자료조차도 수집되지 않아서 봉사 사업의 결과를 논하는 
것조차 불가능한 경우가 많다. 사례연구들은 많지만, 성공사례·우수사례의 정보와 데이터를 적절히 활용하여 문서화하는 체계가 부족하다는 점도 문제가 되고 있다. 이처럼 기초 자료의 부재는 정확하고 객관적인 자료에 근거한 자료가 아닌 입증되지 않은 증거(anecdotal evidence) 자료에 의존하게 될 수밖에 없다(Lough et al., 2015:19).

기초선 부재의 문제뿐만 아니라, 샘플 수가 부족하여 질적 인터뷰 및 포커스 그룹 인터뷰 방식을 통해 프로젝트를 평가하는 것 또한 다수 해외봉사 성과 평가의 질적 결함으로 지적된다. 간혹 샘플 수가 충분하고 샘플의 대표성이 우수하다 하더라도, 대부분의 보고서에는 기초선 조사가 부재하거나 기초선 조사의 품질이 낮고, 이는 프로그램의 영향력에 대한 결론을 내리는 데 어려움을 준다. 뿐만 아니라 2차 연구 또는 문헌연구(desk review)도 프로그램에 대한 심층 분석이 부족하므로 별로 유용하지 않다고 지적된다(Lough et al., 2015:19).

단원이 지역사회와 기관에 얼마만큼의 장기적 영향을 초래했는지를 단원에게 직접 질문하는 방법도 시도되지만, 이러한 방식의 성과 측정은 대표성과 타당성이 부족하다. 많은 봉사단원이 단기간 파견된 단원이고, 그들은 봉사활동이 본인의 자기계발에는 긍정적 영향을 미쳤을지 모르나, 국제개발에 큰 기여를 하지 않았다고 믿는 경우가 많기 때문이다. 해외봉사활동이 단원 에게 주는 결과가 개발과는 연관성이 없다고 인정하는 평가보고서도 많다(Lough et al., 2015:20).

\section{3) 성과 분석 방법의 한계}

대부분의 해외봉사 성과는 묘사적(descriptive)이거나 탐구적(exploratory) 접근법을 포함 한 간단한 분석방법으로 평가되는 것으로 그치며, 그 이상의 고차원적인 분석방법으로 평가되는 경우가 적다. 이처럼 단편적이고 간단한 분석방법을 택하는 이유는 해외봉사 성과 평가의 설계 가 대부분 비교대조군(comparison groups)이 부족하기 때문이다. 이러한 제한점 때문에 외적 요인을 통제하거나 다중회귀분석(multiple regression analyses) 등과 같은 기본적이며 계량 적인 분석방법을 활용하는 것 또한 어렵다(Lough et al., 2015:20).

상당수 평가자들이 기존 프로그램 결과보고서 및 문서연구(desk studies)를 통한 2차 문헌 연구에 많은 의존을 하는데, 문헌검토는 유용할 수 있지만, 검토의 체계가 일관적이지 않거나 데이터가 부족하고 연구에 공백(gaps)이 있을 경우, 분석의 결론 자체에 결함이 있을 수 있다 (Lough et al., 2015:20).

봉사단원과 프로그램 참가자를 대상으로 1차 현지연구(primary field research)를 실시하는 
경우도 종종 있는데, 이 경우 제일 많이 사용되는 데이터 수집 방법이 봉사단원을 대상으로 한 개별 면담이다. 면담은 봉사단원이 프로그램 설계와 이행에 관하여 긍정적·부정적 관점을 진솔하게 말할 수 있는 기회를 준다. 귀국 봉사단원을 면담하는 방법도 있는데, 이 경우, 귀국 봉사단원이 자신의 경험을 기억해야하는 단점이 있으므로 성과 측정의 객관성과 신뢰도가 떨어 진다. 객관성이 결여된 성과 측정으로는 봉사 프로그램의 진정한 영향을 찾지 못하거나 평가의 결론에 논리적인 결함이 생긴다는 점을 명심해야 한다(Lough et al., 2015:20).

\section{4) 측정 도구의 한계}

해외봉사 성과 측정 도구의 표준화 부족은 성과 데이터 수집 단계에서부터 어려움을 주는 요인이 되며, 이는 세부 목표의 계량화 부재, 연구 설계의 구체성 부족 등과도 관계가 있다. 예를 들어 단원이나 수원기관을 대상으로 시행하는 설문조사에 이용되는 용어가 표준화되어있 지 않다면, 응답 데이터의 기록과 해석을 주관적이고 불규칙적으로 만들며, 이는 성과 측정의 신뢰도를 떨어트린다. 때문에 양질의 성과 평가를 위해서는 해외봉사의 성과 측정 도구 표준화 가 우선 이루어져야 할 필요가 있다.

$\operatorname{Haddock}$ (2016)에 의하면, 측정은 다양한 수준에서 이루어져야 하는데, 봉사단원 개인 수준, 조직 수준, 이슈·지역사회 및 세부 봉사단 그룹 수준, 국가수준(예: 국가 봉사활동 전수조사 등), 글로벌 수준에서 데이터 확보가 가능해야 한다. 특히 국가수준의 데이터 확보에 있어서 국제노동기구(International Labour Organization, 이하 ILO)에서 발간한 봉사활동 측정지 침은 유용한 도구가 될 수 있다.

\section{5) 봉사활동 측정을 위한 ILO 지침}

2011년 발간된 '봉사활동 측정을 위한 ILO 지침(The ILO Manual on the Measurement of Volunteer Work)'은 ILO, 존스홉킨스 대학 시민사회연구센터(Johns Hopkins Centre for Civil Society Studies, CCSS), 국제기술전문조직(International Technical Experts Group)의 합작으로 제작되었으며, 5 개국에서 현지 검증을 거친 지침이다.

$\mathrm{ILO}$ 지침은 봉사활동에 대한 간단한 설문을 국가 차원에서 정기적으로 수행하는 국가 노동력 조사(labour force survey) 혹은 가구조사(household survey)에 통합하여 응답을 요하 는 설문 형식을 취한다. 동 설문으로 인하여 아래<표 $14>$ 와 같이 다양한 정보를 얻을 수 있다. 
〈표 14〉 국제노동기구(ILO) 설문을 통하여 확보 가능한 정보

질문

(1) 몇 명의 사람들이 봉사활동을 하는가? 봉사자들의 인구통계학적 특징은 무엇인가?

(2) 봉사자들이 어떤 종류의 노동에 종사하고 있는가?

(3) 봉사활동에 몇 시간을 할애했는가?

(4) 봉사자들이 어떠한 조직에서 활동했는가? 혹은 어떠한 조직을 통해서 활동했는가?

(5) 봉사자들의 노력은 어떤 부문에 초점이 맞춰있는가(예: 보건, 교육 등)?

(6) 상기 영역들에 대한 국가 간 차이점이 무엇인가?

출처: ILO (2011)의 내용을 저자가 정리 재구성

동 설문에서 $\mathrm{ILO}$ 가 정의하는 자원봉사활동은 '자원봉사자 자신의 가계나 친지가 아닌 타인의 이익을 위해 법적 강제에 의하지 않고 금전적 지급이나 보상이 없는 노동(work)'이다 (ILO, 2011:13). 아래 <표 15>는 ILO가 정의하는 자원봉사활동 개념의 특징을 정리하여 보여준다.

〈표 15〉 국제노동기구(ILO)가 정의하는 봉사활동 개념의 특징

\begin{tabular}{|c|c|}
\hline 요약 & 내용 \\
\hline 이타적 & $\begin{array}{l}\text { 자원봉사자 자신이 아닌 타인에게 경제적 가치를 가진 ‘노동’이어야 하며, ‘노동' 이 } \\
\text { 타인에게 혜택이 되어야만 자원봉사로 간주할 수 있음. 자신의 즐거움을 위한 악기연 } \\
\text { 주는 ‘노동’이 아니므로 자원봉사에 해당되지 않음. }\end{array}$ \\
\hline 무보수 & $\begin{array}{l}\text { 자원봉사에서 의미하는 ‘노동'은 무보수 노동을 말함. 봉사활동에 필요한 경비를 지 } \\
\text { 원받거나 사례금을 받은 '노동’이라고 해서 자원봉사가 아니라고 볼 수는 없으나, } \\
\text { 현물 보상을 받은 ‘노동'은 자원봉사로 간주하기 어려움. }\end{array}$ \\
\hline $\begin{array}{l}\text { 비강제적, } \\
\text { 비의무적 }\end{array}$ & $\begin{array}{l}\text { 자원봉사 ‘노동’은 비강제적, 비의무적이어야 함. 법원의 명령에 의한 무보수 '사회봉 } \\
\text { 사', 군복무에 대한 대체 복무, 졸업에 필수가 되는 무보수 인턴십 등은 자원봉사에 } \\
\text { 해당되지 않음. }\end{array}$ \\
\hline $\begin{array}{c}\text { 공식, 비공식 } \\
\text { 모두 포함 }\end{array}$ & $\begin{array}{l}\text { 공식적 조직이나 단체를 통한 ‘공식' 자원봉사 노동, 혹은 ‘비공식' 자원봉사 노동 } \\
\text { 모두 자원봉사 일에 해당됨. '노동'의 개념 정의에서도 제도적 배경은 상관이 없으므 } \\
\text { 로 자원봉사의 공식, 비공식 구분은 의미가 없음. }\end{array}$ \\
\hline
\end{tabular}

출처: ILO (2011) p.13-16의 내용을 저자가 재구성

주의해야할 점은, 다수의 해외봉사 프로그램에는 활동지원비가 따른다는 점에 있어서 ILO가 정의하는 자원봉사와는 차이가 있다. 하지만 무보수 원칙의 성립 여부를 떠나 ILO 지침은 봉사활동 의 성과 측정에 표준화된 지침을 제공하기 때문에 유용하게 활용될 수 있다(<표 $16>$ 참고). 
〈표 16〉ILO 봉사활동 측정지침의 특징과 장점

\begin{tabular}{|c|c|}
\hline 분류 & 내용 \\
\hline 특징 & $\begin{array}{l}\text { - 봉사(volunteering)에 관해 광범위한 정의를 활용함. } \\
\text { - 조직을 기반으로 하는 봉사활동과 개인이 직접 수행하는 봉사활동 모두를 다룸. } \\
\text { - 봉사자가 수행하는 일(work) 및 봉사활동에 할애하는 시간 수에 관한 정보를 수집함. } \\
\text { - 누가, 얼마나, 누구를 위해, 어떤 봉사활동을 수행하는지 정기적으로 정보를 제공함. } \\
\text { - 봉사활동에 대한 경제적 기여에 대한 기록을 가능케 함. } \\
\text { - 표준화 된 개념 정의와 접근법을 통하여 국가 간 비교를 가능케 함. } \\
\text { - 봉사활동의 가시성과 신뢰성(credibility)을 높임으로써 봉사활동을 장려할 수 있음. } \\
\text { - 현재 노동력 측정 분야에 존재하는 갭(gap)을 채워줄 것임. }\end{array}$ \\
\hline 장점 & $\begin{array}{l}\text { - 비교 가능 : ॥O 지침은 봉사활동에 관한 데이터 수집, 개념 정의, 분류, 요소 등에 공통적 } \\
\text { 접근을 제공함. } \\
\text { - 실현 가능 : 다양한 국가에서, 이행에 관한 최소한의 부담으로, 다양한 전통문화와 언어 } \\
\text { 적 차이를 고려하여 지침을 실현하는 것이 가능함. } \\
\text { - 비용 효과적 : 기존의 가계조사를 활용하고 기존의 분류체계와 구조를 이용함으로써 } \\
\text { 비용을 절약할 수 있음. } \\
\text { - 효율적 : 최소한의 질문 문항을 통하여 최대한의 정보를 수집할 수 있음. } \\
\text { - 신뢰 가능 : 국제기술전문조직의 광범위한 조언과 주요 개념 및 설계에 대한 신중한 } \\
\text { 현장시험(field testing)을 거친 지침임. } \\
\text { - 포괄적 : 현재 가시적이지 않은 노동력에 대한 실질적 집계를 제공해 주어, 무임금 노동 } \\
\text { 에 대한 경제적 영향을 분명하게 밝혀주고, 정책결정자들이 무임금 노동에 대한 잠재력을 } \\
\text { 이해하는데 도움을 제공함. }\end{array}$ \\
\hline
\end{tabular}

출처: Third Sector Impact 홈페이지 내용을 저자가 재구성12)

2013년 ILO는 '일(work activities)'에 대한 정의에 봉사를 포함했는데, 이는 봉사활동이 공식적으로 '일'로 분류되기 시작하면서 봉사활동의 통계적 측정에 대한 근거가 수립되었다는 점에 있어서 고무적이라 할 수 있다(Haddock, 2016).

동 지침은 봉사활동의 특징 및 가치에 대한 정보제공에 관련하여 최초로 국제적 승인을 받은 지침으로, 봉사활동 측정의 기준을 수립하는 노력 중 가장 탁월한 기여로 사료된다 (Franco·Shahrokh, 2012:25). 동 지침 발간으로 인한 가장 주목할 만한 결과로, 봉사활동의 영향과 가치 측정을 위한 새로운 방법론에 대한 관심 증가라 할 수 있다. 그 중 ILO 지침을 정기적으로 이행하는 국가의 증가, 봉사활동 이외에도 자발적 활동(voluntary action) 및 사회 적 측면을 측정하는 통계도구의 모색 증가 또한 고무적인 현상이라 할 수 있다(FrancoShahrokh, 2012:25).

12) Third Sector Impact 홈페이지를 참조하기 바란다. (http://thirdsectorimpact.eu/site/assets/uploads/documentations/ first-tsi-policy-brief-defining-third-sector/GVMP-STATS-9.13.2011.pdf）（접속일: 2016.12.26.） 


\section{VI. 종합분석 및 결론}

지금까지 해외봉사 성과 측정을 주제로 국제사회의 해외봉사 성과 측정 논의와 이론적 접근 법, SDGs와의 연계를 통한 접근법, 그리고 도전과제를 검토하였다. 향후 방향으로, Lough et al.(2015:23)는 해외봉사 프로그램이 보다 강력한 M\&E 체계를 도입할 필요가 있음을 강조 하며, 전 세계 해외봉사 파견기관을 위한 몇 가지 연구 방향을 제언한다(<표 $17>$ 참고).

〈표 17〉 해외봉사 사업의 M\&E 체계 향상을 위한 제언

\begin{tabular}{|c|c|}
\hline 영역 & 내용 \\
\hline $\begin{array}{l}\text { 구체성 및 논리 } \\
\text { 확보 }\end{array}$ & $\begin{array}{l}\text { 산출물과 결과를 탐구하는데 있어서 연구 주제 · 질문을 뚜렷하고 개념적으로 } \\
\text { 논리가 촘촘하도록 설계할 것 }\end{array}$ \\
\hline 변화이론 활용 & $\begin{array}{l}\text { 연구와 평가 설계에 변화이론을 기본으로 함으로써 프로그램, 결과, 결과를 중재 } \\
\text { 하는 요소들 간의 논리적 연계를 도모할 것 }\end{array}$ \\
\hline 계량화 & $\begin{array}{l}\text { 봉사단원의 활동이 개발에 주는 결과를 측정할 수 있도록 계량적 측정법을 고안 } \\
\text { 할 것 }\end{array}$ \\
\hline $\begin{array}{l}\text { 외부요인 자료 } \\
\text { 수집 }\end{array}$ & $\begin{array}{l}\text { 봉사활동 이외의 외부적 요인에 대한 데이터도 함께 수집하여 봉사 서비스가 } \\
\text { 주는 결과에 대한 귀인이 가능토록 할 것 }\end{array}$ \\
\hline 행동변화에 초점 & $\begin{array}{l}\text { 태도나 믿음의 변화 같은 추상적인 것을 측정하기보다는, 행동에 대한 변화를 } \\
\text { 직접적으로 측정할 것 }\end{array}$ \\
\hline $\begin{array}{l}\text { 측정과 분석 수준 } \\
\text { 일치 }\end{array}$ & $\begin{array}{l}\text { 측정의 단위·수준과 분석의 단위·수준이 일치하도록 할 것 (예: 봉사단원들에 } \\
\text { 대한 영향 측정은 봉사단원 설문조사를 통해 실시, 지역사회 차원의 영향을 측정 } \\
\text { 하기 위해서는 지역사회 설문조사를 실시 등) }\end{array}$ \\
\hline $\begin{array}{l}\text { 양적, 질적 연구 } \\
\text { 활용 }\end{array}$ & $\begin{array}{l}\text { 봉사단원이 개발사업에 주는 기여의 복잡함에 대해 보다 잘 이해하도록 양적, } \\
\text { 질적 연구를 모두 활용할 것 }\end{array}$ \\
\hline 실험 디자인 & $\begin{array}{l}\text { 되도록 실험(예: RCT) 및 준 실험 디자인을 통하여 영향을 평가하는 것을 목표로 } \\
\text { 두되, 반 사실적/사후 가정 측정과 사전-사후 검증(pre-post test) 디자인을 이용 } \\
\text { 하는 것이 인과관계 설명을 가능케 하는데 필수라는 점을 명심할 것 }\end{array}$ \\
\hline
\end{tabular}

출처: Lough et al. (2015) p.23 정리 및 재구성

위의 사항을 참고하여 $\mathrm{WFK}$ 의 중장기적 성과 측정 체계를 위한 전략 방향은 첫째, $\mathrm{WFK}$ 통합성과체계의 논리성, 구체성 확보이다. 5 개의 소관부처 및 7 개 시행기관에서 담당하고 있는 각기 다른 세부 WFK 프로그램을 논리적으로 통합하고, 이에 따라 WFK 공통 성과 측정 틀을 수립해야 할 것이며, WFK 프로그램별로 특성화된 세부적 성과 틀을 마련해야 할 것이다.

예를 들어, 현재 각기 다른 WFK 봉사단이 개도국 주민들의 삶의 질 향상, 개도국과 한국 간의 우호 협력과 상호 이해 증진, 단원 자신의 자아실현과 성장을 공통적 파견 목표로 지향하고 있다는 점에 착안하여 WFK 통합 성과관리 지표가 개발 중에 있다(예: 홍문숙 외, 2016). 한편 $\mathrm{WFK}$ 활동이 수원국에게 주는 중장기적 영향은 장기봉사단(예: 파견기간이 1 2년인 월드프렌 
즈 $\mathrm{KOICA}$ 봉사단)과 단기봉사단(예: 2 3주 활동하는 월드프렌즈 청년봉사단) 간에 분명 차이 가 있을 것이다. 또한 주력분야 및 직종도 고려해야 할 필요가 있다. 예를 들어, 월드프렌즈 태권도평화봉사단(태권도 교육 중점)과 월드프렌즈 IT 봉사단(IT 전문인력 파견 중점) 간의 성과 측정 틀과 지표에는 분명한 차별성이 있어야 할 것이다. 즉 $\mathrm{WFK}$ 의 성과 평가 틀과 지표는 세부 프로그램, 분야, 직종의 고유 특성과 차이점을 반영해야만 논리적인 틀이 될 것이다.

둘째, WFK 성과 평가에서 변화이론의 활용과 SDGs 주류화를 위한 구체적 방안 마련이 필요하다. WFK의 향후 성과 측정 틀은 현재 진행 중인 $\mathrm{WFK}$ 지표개발 작업에 사용된 변화이 론(논리모형)을 유지하되, 세부적 성과요소들 간의 논리적 연계를 심화하고 SDGs 와의 관련성 을 보다 가시적으로 드러내야 할 것이다. 이를 위해 본문에서 알아본 SDGs mapping 기법을 논리모형에 접목하여, 아래와 같이 WFK 중장기 개발성과 측정을 위한 SDGs 연계모델(안) 수립해 볼 수 있다.

먼저, 월드프렌즈 KOICA 봉사단의 보건교육 프로그램 직종을 예로 들자면, 동 직종의 구체 적인 활동 예시는 다음과 같다(<표 $18>$ 참고).

〈표 18〉 월드프렌즈 KOICA 봉사단 보건교육 프로그램 봉사단(Health Extension Program Volunteer) 활동 개요

\begin{tabular}{|c|c|c|}
\hline 분류 & \multicolumn{2}{|r|}{ 내용 } \\
\hline 목표 & \multicolumn{2}{|c|}{ 지역사회 주민들의 보건 습관 개선교육을 통한 보건 환경 개선에 기여 } \\
\hline 파견형태 & \multicolumn{2}{|c|}{$\begin{array}{l}\mathrm{KOICA} \text { 보건교육 프로그램 봉사단은 팀제로 운영되며, 간호사 } 1 \text { 명, 보건 분야 전문가 } \\
1 \text { 명, 환경 분야 전문가 } 1 \text { 명, 영양 분야 전문가 } 1 \text { 명, 대외협력 } 1 \text { 명, 업무보조 } 1 \text { 명 총 } 6 \text { 인 } \\
\text { 내외가 } 1 \text { 팀으로 활동 }\end{array}$} \\
\hline 활동형태 & \multicolumn{2}{|c|}{$\begin{array}{l}\text { 보건부, 교육부 등 정부기관 소속으로 보건교육 시스템이 열악한 마을, 초 · 중 · 고등학교 } \\
\text { 등지에서 관련 교육, 캠페인 및 프로젝트 실시 }\end{array}$} \\
\hline \multirow{4}{*}{$\begin{array}{l}\text { 주요활동 } \\
\text { 내용 }\end{array}$} & 보건 분야 & $\begin{array}{l}\text { 모자보건, 성교육, 성병교육, 가족계획, 질병예방(말라리아 등), 개인위생 교 } \\
\text { 육, 보건 개선을 위한 현장 사업 등 }\end{array}$ \\
\hline & 환경 분야 & $\begin{array}{l}\text { 기숙사 등 환경 개선 교육, 공공시설(화장실 등) 이용 시 에티켓 교육, 환경 } \\
\text { 개선을 위한 현장 사업 등 }\end{array}$ \\
\hline & 영양 분야 & $\begin{array}{l}\text { 클러스터 내 주민들 영양상태 체크, 영양 개선을 위한 식단 제공, 영양 개선 } \\
\text { 인식 교육, 영양 개선을 위한 현장 사업 등 }\end{array}$ \\
\hline & $\begin{array}{l}\text { 대외협력 } \\
\text { 분야 }\end{array}$ & $\begin{array}{l}\text { 통역, 현지 기관장, 관계부처, KOICA 사무소 등과의 커뮤니케이션 업무, } \\
\text { 보건-환경-영양 업무보조, 논문작성에 필요한 자료 수집 및 논문작성, ICT } \\
\text { 기초교육, 영어기초교육, 문화 ODA(한국 음식-김밥, 한국 문화-한국영화 } \\
\text { 상영 등), 행정업무 등 }\end{array}$ \\
\hline
\end{tabular}

출처: KOICA (2016C)를 참고하여 저자가 재구성 
상기 활동은 SDGs 세 번째 목표(보건과 복지)에 분명하게 기여한다.

〈표 19〉 월드프렌즈 KOICA 봉사단 보건교육 프로그램 봉사단과 SDG 3(보건복지) 간의 연계

\begin{tabular}{|l|l|}
\hline \multicolumn{1}{|c|}{ 봉사활동 내용 } \\
$\begin{array}{l}\text { 지역사회 주민들에게 보건 습관 개선교육을 제 } \\
\text { 공한다. }\end{array}$
\end{tabular}$\rightarrow$\begin{tabular}{l}
\multicolumn{1}{c|}{ SDG 3(보건과 복지) } \\
$\begin{array}{l}\text { 모두를 위한 전 연령층의 건강한 삶을 보장하고 } \\
\text { 복지를 증진한다. }\end{array}$ \\
\hline
\end{tabular}

출처: KOICA (2016b) 및 UN (2016)를 참고하여 저자가 작성

동 봉사활동은 보건복지 목표뿐만 아니라 여성의 권한 강화(여성들에게 성교육, 모자보건, 가족계획 교육을 제공할 경우), 기아 종식 및 영양 개선(주민들의 영양상태 체크 및 영양 개선 인식 교육 실시), 파트너십 개발 및 강화(관계부처 및 현지 기관장 등과 협력)에도 함께 기여하 여 $\mathrm{SDG}$ 달성에 동시다발적으로 연계가 된다(<표 20> 참조).

〈표 20〉 월드프렌즈 해외봉사단 파견 사업(WFK) 활동과 SDGs 간의 연계 mapping

\section{활동 내용 (월드프렌즈 KOICA 봉사단 보건교육 프로그램 봉사단)}

- (보건) 모자보건, 성병 및 성교육, 가족계획, 질병예방(말라리아, 파상 풍, 광견병 등), 응급의료지식, 개인위생 교육, 관련 프로젝트

- (환경) 쓰레기 처리 방법 및 재활용 방법, 친환경 가정집 꾸리기, 폐수 및 오수 처리 방법 교육 및 관련 프로젝트

- (영양) 나이대별 적절한 식이법 교육 및 관련 프로젝트

- (대외협력) 통역, 홍보, 대외연락, 국제시민사회교육(ICT, 영어, 한국 어, 한국 문화 $\mathrm{ODA}$ 등) 등

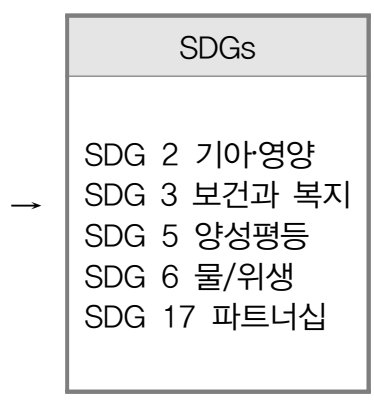

출처: KOICA (2016b) 및 UN (2016)를 참고하여 저자가 작성

상기 표에서 명시한 특정 활동 외에도 WFK 일반봉사단의 타 활동 및 직종 사례 별로 SDGs 와 연계가 가능하다.

〈표 21〉 월드프렌즈 해외봉사단 파견 사업(WFK) 일반봉사단 주력직종별 활동 내용과 SDGs 간 연계

\begin{tabular}{|c|c|c|c|c|}
\hline 분야 & 활동 직종 & 활동 사례 예시 & & SDGs 연계 예시 \\
\hline \multirow[b]{2}{*}{ 교육 } & \multirow{2}{*}{$\begin{array}{c}\text { 미술교육 } \\
\text { (미술교사) }\end{array}$} & 지역 특산품을 이용한 공예품 제작 교육 & $\rightarrow$ & $\begin{array}{l}\text { SDG } 4 \text { 교육 } \\
\text { SDG } 11 \text { 도시/지역사회 } \\
\text { SDG } 12 \text { 생산/소비 }\end{array}$ \\
\hline & & 수익원 창출을 위한 공예품 제작 교육 지원 & $\rightarrow$ & $\begin{array}{l}\text { SDG } 4 \text { 교육 } \\
\text { SDG } 8 \text { 일자리 } \\
\text { SDG } 12 \text { 생산/소비 }\end{array}$ \\
\hline
\end{tabular}




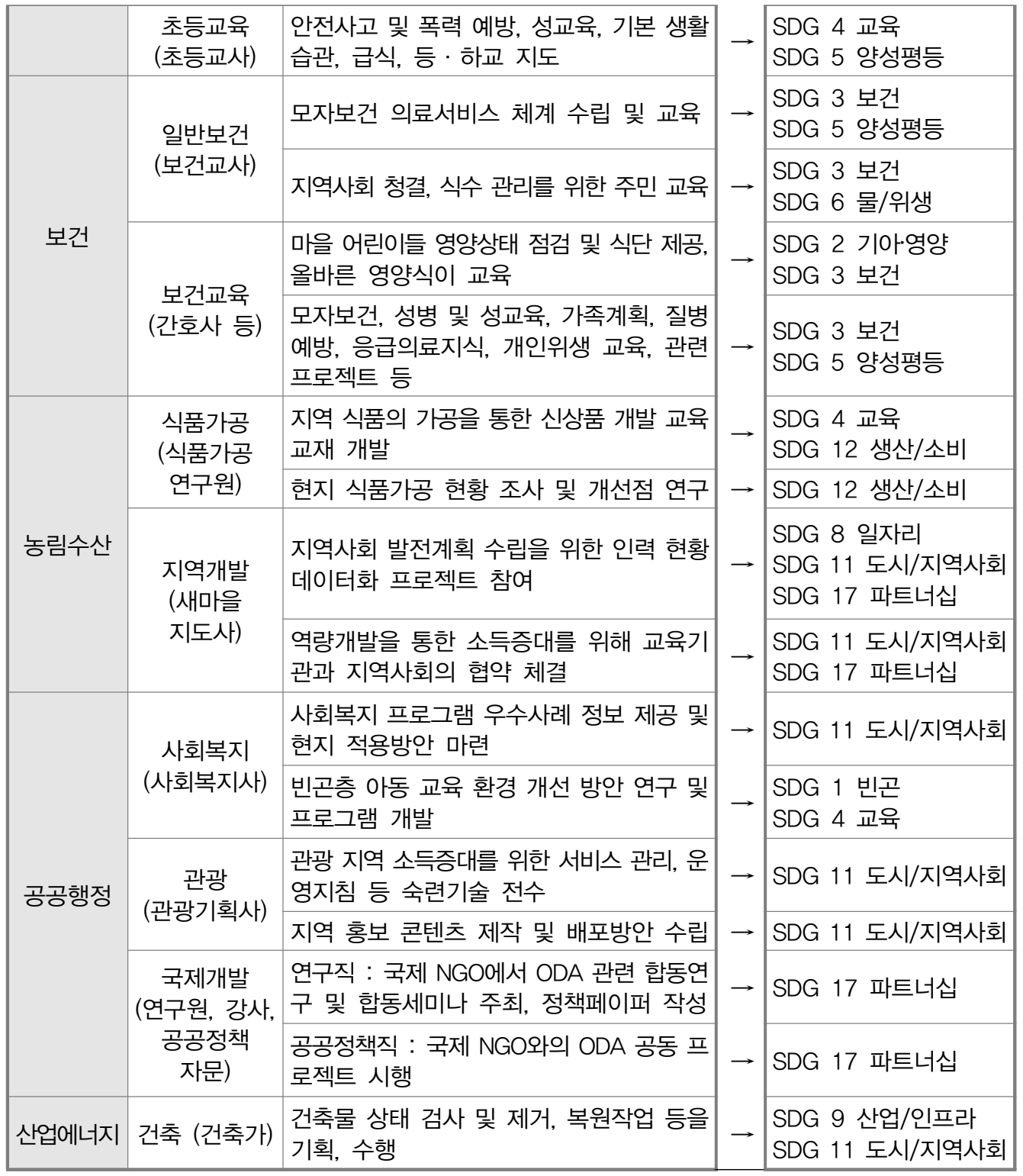

출처: KOICA (2016b) 및 UN (2016)를 참고하여 저자가 작성

참고: 2016년도 일반 봉사단 주력직종은 상기 표에 명시된 직종을 포함하여 총 38개(미술교사, 건축가 등) 직종 및 직종별로 수많은 활동 예시가 있으나, 상기 표는 그중 SDGS와 연계가 분명한 사례를 선정하여 보여주고 있다.

위의 mapping은 다시 SDGs 세부 목표 수준으로 나누어서 mapping 할 수 있다. 예를 들어, 월드프렌즈 KOICA 봉사단의 보건교육 프로그램의 경우 아래 <표 $22>$ 의 예시와 같은 mapping 이 가능하다. 
〈표 22〉 월드프렌즈 KOICA 봉사단(보건교육 프로그램 봉사단) 활동과 SDGs 목표· 세부 목표 간의 Mapping 모델 예시

\begin{tabular}{|c|c|c|}
\hline 봉시 & & SDGs 및 세부 목표 \\
\hline \multirow[b]{4}{*}{$\begin{array}{l}\text { (보건) 모자보건, 성병 및 } \\
\text { 성교육, 가족계획, } \\
\text { 질병예방, 응급의 } \\
\text { 료지식, 개인위생 } \\
\text { 교육, 관련 프로젝 } \\
\text { 트 } \\
\text { (환경) 쓰레기 처리 방법. } \\
\text { 재활용 방법, 친 } \\
\text { 환경 가정집 꾸리 } \\
\text { 기, 폐수 및 오수 } \\
\text { 처리 방법 교육, } \\
\text { 관련 프로젝트 }\end{array}$} & & SDG 2 기아영양 \\
\hline & & $\begin{array}{l}\text { - } 2.1 \text { 기아 종식 및 빈곤층 및 영 - 유아를 포함한 취약계층이 연중 } \\
\text { 안전하고 영양가 있으며 충분한 식량에 접근하도록 보장 } \\
\text { - 2.2 유아 발육부진·체력 저하에 대응, 영양결핍 종식, 청소년기 소 } \\
\text { 녀와 임산부, 수유여성 및 노년층의 영양상 필요에 대응 }\end{array}$ \\
\hline & & $\mathrm{SDG} 3$ 보건과 복지 \\
\hline & & $\begin{array}{l}\text { - } 3.1 \text { 전 세계적으로 산모 사망 비율 감축 } \\
\text { - } 3.2 \text { 신생아-유아의 예방 가능한 사망 종식 및 신생아 사망 감축 } \\
\text { - } 3.3 \text { 전염병 및 열대풍토성 소외질환 종식 및 간염, 수인성 질병, } \\
\text { 기타 전염성 질병 방지 } \\
\text { - } 3.4 \text { 예방치료를 통하여 비전염성 질병으로 인한 조기 사망을 감축, } \\
\text { 정신건강 및 복리 증진 } \\
\text { - } 3.7 \text { 가족계획 등을 포함한 성 생식 보건 서비스에 대한 보편적 } \\
\text { 접근과 생식 보건의 국가 전략 및 프로그램에의 통합 보장 } \\
\text { - } 3.8 \text { 양질의 필수 보건 서비스에 대한 접근 및 필수 의약품과 백신에 } \\
\text { 대한 접근을 포함한 보편적 의료 보장 달성 } \\
\text { - } 3.9 \text { 유해 화학물질과 대기· 물 · 토양 공해 및 오염으로 인한 사망과 } \\
\text { 질병 건수를 감축 }\end{array}$ \\
\hline \multirow{3}{*}{$\begin{array}{c}\text { (영양) 나이대별 적절한 } \\
\text { 식이법 교육, 관 } \\
\text { 련 프로젝트 }\end{array}$} & & SDG 5 양성평등 \\
\hline & & - 5.6 성 - 생식 보건과 생식권에 대한 보편적 접근 보장 \\
\hline & & SDG 6 물/위생 \\
\hline \multirow[t]{3}{*}{$\begin{array}{l}\text { (대외협력) 통역, 홍보, } \\
\text { 대외연락, 국제시 } \\
\text { 민사회교육 등 }\end{array}$} & & $\begin{array}{l}\text { - } 6.2 \text { 모두를 위한 적절하고 공평한 공중위생 및 개인위생에 대한 } \\
\text { 접근을 달성, 노상배변 종식 } \\
\text { - } 6.3 \text { 오염 감축, 유해 화학물물질의 투기 근절과 방출 최소화, 미처 } \\
\text { 리 폐수 비율 반감(半減), 재활용재사용 증진을 통해 수질 개선 } \\
\text { - 6.a 물위생 관련 활동과 프로그램에 있어서의 국제적 협력 및 개도 } \\
\text { 국에 대한 역량 구축 지원 확대 } \\
\text { - } 6 . b \text { 물·위생관리 개선에 지역공동체의 참여 지원 및 강화 }\end{array}$ \\
\hline & & SDG Goal 17: 이행수단 및 파트너십 강화 \\
\hline & & $\begin{array}{c}\text { - } 17.16 \text { 지식 · 전문성 · 기술 · 재원을 동원 · 공유하는 다주체 파트 } \\
\text { 너십 등을 통한 글로벌 파트너십 강화 }\end{array}$ \\
\hline
\end{tabular}

출처: KOICA (2016b) 및 UN (2016)를 참고하여 저자가 작성

상기 표는 월드프렌즈 $\mathrm{KOICA}$ 봉사단의 활동 요소가 SDGs의 어떤 목표와 세부 목표에 기여하는지를 명백히 보여준다. 더 나아가 상기 mapping을 SDGs 달성을 위한 투입, 산출물, 결과, 영향에 대한 논리모형과 접목하여 발전시킬 수 있다. 예를 들어, 아래의 <표 23>은 월드 프렌즈 $\mathrm{KOICA}$ 봉사단의 활동이 SDGs에 어떻게 기여하는지를 보여준다. 
〈표 23〉 월드프렌즈 KOICA 봉사단 보건교육 프로그램 봉사단 활동의 SDGs 기여 mapping 논리모형

\begin{tabular}{|c|c|c|}
\hline \multicolumn{3}{|c|}{ 영향 : SDG 3 (보건과 복지) } \\
\hline \multicolumn{3}{|c|}{ 모두를 위한 전 연령층의 건강한 삶을 보장하고 복지를 증진한다. } \\
\hline $\begin{array}{l}\text { 활동 내용 } \\
\text { (예시) 니니모형 } \\
\text { (봉사활동의 가여) }\end{array}$ & $\begin{array}{l}\text { 세부 활동 } 1 \text { (예시) : 지역사회 주민들 } \\
\text { 의 영양상태 체크 서비스 및 영양 개선 } \\
\text { 을 위한 조언·식단 제공 }\end{array}$ & $\begin{array}{l}\text { 세부 활동 } 2 \text { (예시) : 성인 부부를 대상 } \\
\text { 으로 가족계확·피임 교육 제공 }\end{array}$ \\
\hline SDGs와 연계 & -SDG 2 기아 및 영양 & $\begin{array}{l}\text { - SDG } 3 \text { 보건복지 } \\
\text { - SDG } 5 \text { 양성평등 }\end{array}$ \\
\hline 영향 & $\begin{array}{l}\text { - 영양부족 } 50 \% \text { 감소 } \\
\text { - 귀국봉사단원이 } \$ 20 \mathrm{k} \text { 재정 동원 } \\
\text { - 영양 정책 변화 달성 }\end{array}$ & $\begin{array}{l}\text { - 안전하고 효과적인 피임법을 사용하 } \\
\text { 는 부부 수 } 30 \% \text { 증가 } \\
\text { - 원치 않는 임신출산 } 20 \% \text { 감소 } \\
\text { - 원치 않는 임신 감소에 따라 경제활동 } \\
\text { 참여 여성 수 } 20 \% \text { 증가 }\end{array}$ \\
\hline $\begin{array}{c}\text { 결과 } \\
\text { (프로그램 성과 } \\
\text { 내용) }\end{array}$ & $\begin{array}{l}\text { - } 50 \text { 개 사례에서 주민(영·유아 포함) 영 } \\
\text { 양부족 문제 감지 및 조치 } \\
\text { - 봉사단원의 기술, 역량, 자신감 향상 } \\
\text { 에 따른 새로운 역할 채택 } \\
\text { - 귀국 단원의 파트너 지원 통해 정책 } \\
\text { 변화를 위한 기금 신청 및 로비 }\end{array}$ & $\begin{array}{l}\text { - 50쌍의 부부가 교육에서 배운 정보를 } \\
\text { 활용했다고 보고 } \\
\text { - 가족계획 및 피임 정보를 타인과 공유 }\end{array}$ \\
\hline $\begin{array}{l}\text { 산출물(서비스 } \\
\text { 수혜자 수, 지원된 } \\
\text { 서비스 · 물품 수) }\end{array}$ & $\begin{array}{l}\text { - 서비스 수혜자 } 600 \text { 명 } \\
\text { - 영양상태 체크 및 조언제공 } 300 \text { 건 } \\
\text { - } 30 \text { 개의 공동체가 서비스 수혜 } \\
\text { - } 2 \text { 개의 개도국이 서비스 수혜 }\end{array}$ & $\begin{array}{l}\text { - } 100 \text { 쌍의 부부가 훈련 수혜 } \\
\text { - 훈련 완료 및 콘돔 수령 } 100 \text { 건 } \\
\text { - } 10 \text { 개 공동체가 훈련 수혜 } \\
\text { - } 2 \text { 개 국가에서 훈련 수혜 }\end{array}$ \\
\hline $\begin{array}{l}\text { 투입 } \\
\text { (수원국) }\end{array}$ & $\begin{array}{l}\text { - 60명의 지역봉사단원 투입 } \\
\text { - } 600 \text { 시간 투입 }\end{array}$ & $\begin{array}{l}\text { - } 10 \text { 명의 지역봉사단원 투입 } \\
\text { - 250시간 투입 }\end{array}$ \\
\hline $\begin{array}{c}\text { 투입 } \\
\text { (공여국) }\end{array}$ & $\begin{array}{l}\text { - } 1 \text { 명의 단원(영양학 석사) 투입 } \\
\text { - } 200 \text { 시간 투입 } \\
\text { - } \$ 8,000 \text { 비용 발생 }\end{array}$ & $\begin{array}{l}\text { - 2명의 단원(간호사, 보건학 석사) 투입 } \\
\text { - 200시간 투입 } \\
\text { - } \$ 2,500 \text { 비용 발생 }\end{array}$ \\
\hline
\end{tabular}

출처: KOICA (2016b) 및 UN (2016)를 참고하여 저자가 작성

위와 같이 논리모형에 SDGs를 접목함으로써 $\mathrm{WFK}$ 봉사단의 구체적 활동에 따른 영향, 그리고 이의 SDGs 와의 논리적 연계를 심화할 수 있다. 위와 같은 모델을 각 WFK 프로그램이 나 직종별로 설계할 수 있을 것이며, 특히 기 설정된 SDGs 측정지표(UN, 2016)는 WFK 활동의 성과지표 풀 수립에도 용이하게 활용될 수 있다.

예를 들어, 활동 1 과 활동 2 에 대한 성과 측정 지표의 풀은 SDGs 측정지표를 참고하여 다음 <표 $24>$ 와 같이 설정할 수 있다. 
〈표24〉 월드프렌즈 KOICA 봉사단 보건교육 프로그램 봉사단 활동의 SDGs 기여 측정을 위한 성과 지표 풀 예시

\begin{tabular}{|c|c|}
\hline $\begin{aligned} \text { 세부 활동 } 1 \text { (예시) : } & \text { 지역사회 주민들의 영양상태 } \\
& \text { 체크 서비스 및 영양 개선을 } \\
& \text { 위한 조언·식단 제공 }\end{aligned}$ & $\begin{array}{c}\text { 세부 활동 } 2 \text { (예시) : 성인 부부를 대상으로 가족계 } \\
\text { 획·피임 교육 제공 }\end{array}$ \\
\hline SDG 2 기아 영양 & SDG 3 보건복지 \\
\hline $\begin{array}{l}\text { - 세부 목표 } 2.1 \text { 기아 종식 및 빈곤층 및 영·유아 } \\
\text { 를 포함한 취약계층이 연중 안전하고 영양가 있 } \\
\text { 으며 충분한 식량에 접근하도록 보장 } \\
\text { - 측정지표 2.1.1 영양부족 현황 }\end{array}$ & $\begin{array}{l}\text { - 세부 목표 } 3.7 \text { 가족계획 등을 포함한 성 · 생식 } \\
\text { 보건 서비스에 대한 보편적 접근과 생식 보건의 } \\
\text { 국가 전략 및 프로그램에의 통합 보장 } \\
\text { - 측정지표 3.7.1 현대적인 피임법을 사용하는 } \\
\quad \text { 가임기 여성(15-49세)의 비중 }\end{array}$ \\
\hline \multirow{2}{*}{$\begin{array}{l}\text { - 세부 목표 } 2.2 \text { 유아 발육부진체력저하에 대응, } \\
\text { 영양결핍 종식, 청소년기 소녀와 임산부, 수유여 } \\
\text { 성 및 노년층의 영양상 필요에 대응 } \\
\text { - 측정지표 2.2.1 } 5 \text { 세 이하 유아의 발달저해 현 } \\
\quad \text { 황 } \\
\text { - 측정지표 2.2.2 } 5 \text { 세 이하 유아의 종류별(소모 } \\
\quad \text { 성, 과체중) 현황 }\end{array}$} & SDG 5 양성평등 \\
\hline & $\begin{array}{l}\text { - 세부 목표 } 5.6 \text { 성 - 생식 보건과 생식권에 대한 } \\
\text { 보편적 접근 보장 } \\
\text { - 측정지표 } 5.6 .1 \text { 재생산권리, 피임도구 사용, 성 } \\
\text { 관계 등에 대해 충분한 정보를 바탕으로 결정 } \\
\text { 을 내릴 수 있는 } 15-49 \text { 세 여성 비중 }\end{array}$ \\
\hline
\end{tabular}

출처: KOICA (2016b) 및 UN (2016)를 참고하여 저자가 작성

위의 표에서 제안한 WFK의 SDGs 성과지표와의 연계는 WFK 프로그램의 타 세부 활동을 위해서도 도출이 가능하다. 이처럼 WFK 프로그램을 SDGs와 연계하여 세부 목표, 영향, 성과 측정 풀을 도출하는 작업은 $\mathrm{WFK}$ 프로그램 성과 평가의 중장기 전략 구체화의 초석이 될 수 있을 것이다. 


\section{〈참고문헌〉}

구영은·최경화·손성경. 2016. "WFK 중장기 전략 수립을 위한 수원국 중심의 해외봉사단

성과 요소 분석.” 『국제개발협력』 2016-3호: 109-144. 성남: 한국국제협력단. 이태주·박근혜·김헌·고은경·이순열·강하니·오연주·이선주·천유진·추빛나. 2016. "KOICA

해외봉사단사업 종합평가 최종보고서.” 서울: (사)글로벌발전연구원.

주성수·조영호·이란희·김이경. 2016. 『해외봉사단 효과성 증진을 위한 봉사단 분야별,

직종별 추진 전략』. 서울: 한양대학교 제 3 섹터연구소.

주성수·김현옥·이금룡·정희선·송정안·천희·이란희. 2012. "자원봉사활동 진흥을 위한 제

2차 국가기본계획(2013-2017) 최종 연구보고서.” 서울: 행정안전부·(사)한국자원봉

사협의회.

한국국제협력단. 2016a. 『2015 월드프렌즈코리아 통합 만족도조사 결과보고서』 성남:

한국국제협력단.

. 2016b. “2016년도 일반봉사단 주력직종 정의 및 분류”(내부자료). 성남: 한국국 제협력단.

2016c. "월드프렌즈 KOICA 봉사단 공식 수요요청서: 39. 보건교육프로그램" (내부자료). 성남: 한국국제협력단.

2016d. "한눈에 읽는 2015년 World Friends Korea 주요통계.” 성남: 한국국제 협력단.

홍문숙·김헌·이순열·이선주·남종민·추빛나·이희철. 2016. 『월드프렌즈사업 성과관리 지표개발 연구.』서울: (사)글로벌발전연구원.

Allum, C. 2016. "Forum Discussion Paper 2016 - Why measure and for whose benefit? Addressing the challenges of measuring the contribution of volunteering for development in a multiple stakeholder environment." 9th-12th October, 2016, Bonn, Forum.

Binnendijk, A. 2000. "Results based management in the development cooperation agencies: a review of experience - Background Report." Paris: OECD DAC.

Burns, D., Picken, A., Hacker, E., Aked, J., Turner, K., Lewis, S., and Franco, E. L. 2015. "The role of volunteering in sustainable development." London: 
VSO and IDS.

Franco, L. E., and Shahrokh, T. 2015. "The changing tides of volunteering in development: Discourse, knowledge and practice." IDS Bulletin vol.46(5):17-28.

2012. "Valuing volunteering - Literature review." London: VOS and IDS.

Haddock, M. 2016. "Measuring the contribution of volunteering to the SDGs: Challenges and Opportunities," presented at the UNV Partnership Forum on 15th October, 2016, Bonn.

Haddock, M., and Devereux, P. 2015. "Forum discussion paper 2015: Documenting the contribution of volunteering to the SDGs: The challenges and opportunities of universal SDGs," 4th-7th October, 2015, Tokyo.

ILO. 2011. "Manual on the measurement of volunteer work." Geneva: ILO.

Lough, B. J., 2015. “The Evolution of International Volunteering.” Written for presentation at the International Volunteer Service Exchange Conference, 12-13 October 2015, Beijing, China. Bonn: UNV.

Lough, B, J., Thomas, M., and Asbill, M. A., 2015. "International volunteering for development: A desk review of Forum members" grey literature. IL: University of Illinois at Urbana Champaign.

Morra-Imas, L. G., Morra, L. G., and Rist, C. R., 2009. "The road to results: Designing and conducting effective development evaluations.” 한국국제 협력단 역. Washington, D.C.: World Bank.

UN. 2014. "The road to dignity: ending poverty, transforming all lives and protecting the planet." (A/69/700). New York: UN.

2015. "Transforming our world: the 2030 Agenda for Sustainable Development.” (A/RES/70/1). New York: UN.

2016. "Report of the Inter-Agency and Expert Group on Sustainable Development Goal Indicators.” (E/CN.3/2016/2/Rev.1). New York: UN.

UNV. 2011a. "Assessing the contribution of volunteering to development: A participatory methodology: Handbook for UN Volunteers, Programme Officers and Managers.” Bonn: UNV Evaluation Unit. 2011b. "2011 State of the World's Volunteerism Report: Universal 
Values for Global Well-being.” Bonn: UNV.

월드프렌즈 코리아 홈페이지: http://www.worldfriendskorea.or.kr (접속일: 2016.11.25.)

Third Sector Impact 홈페이지: http://thirdsectorimpact.eu (접속일: 2017.1.2.)

UN Statistics Division(Inter-agency Expert Group) 홈페이지: http://unstats.

un.org/sdgs (접속일: 2016.12.26.)

UNV 홈페이지: https://www.unv.org (접속일: 2016.11.25.)

제 I 장 